\title{
Denmark: Mesolithic Coastal Landscapes Submerged
}

\author{
Geoff Bailey, Søren H. Andersen, \\ and Thijs J. Maarleveld
}

\begin{abstract}
Denmark has the richest concentration of underwater Stone Age finds in the world, thanks to a combination of factors that include favourable conditions of preservation and a long tradition of professional and amateur interest in underwater prehistory. The majority of finds are from the central areas of the Danish Straits and date back to about 8500 years ago, when rising sea level finally created a marine connection between the North Sea and the Baltic Sea. Most are in shallow water, c. 2-5 $\mathrm{m}$ in depth, but sites at greater depth have also been identified. Most fall within the Ertebølle period, between 7400 and 5900 years ago, and include excavations at shoreline settlements such as Tybrind Vig, Ronæs Skov and Møllegabet II. These sites have yielded large assemblages of material
\end{abstract}

G. Bailey $(\bowtie)$

Department of Archaeology, University of York, York, UK

College of Humanities, Arts and Social Sciences,

Flinders University, Adelaide, SA, Australia

e-mail: geoff.bailey@york.ac.uk

S. H. Andersen

Moesgaard Museum, Højbjerg, Denmark

e-mail: sha@moesgaardmuseum.dk

\section{T. J. Maarleveld}

Maritime Archaeology Programme, University of Southern Denmark, Esbjerg, Denmark

e-mail: t.maarleveld@sdu.dk including wooden artefacts such as remains of fish weirs, dugout canoes, bows, spear shafts and leister prongs, as well as remains of fibres and woven fabric. These materials owe their excellent state of preservation to the deposition in fine-grained marine sediments alongside settlement areas located on the shoreline, and to subsequent sea-level rise because of marine inundation, which has maintained the material in permanently waterlogged and anaerobic conditions. This chapter examines the conditions that have given rise to this unusual concentration of underwater sites, provides an overview and illustration of some of the most distinctive finds, discusses their wider significance and addresses future challenges.

\section{Keywords}

Boats · Fish weirs - Submerged settlements · Shell mounds $\cdot$ Wooden artefacts $\cdot$ Mesolithic · Kongemose · Ertebølle

\subsection{Introduction}

Denmark has one of the largest concentrations of Stone Age underwater sites in Europe or indeed anywhere else in the world. Estimates of the total number vary, ranging from 2300 (Fischer 2004, p. 23) to as many as 4000 (Andersen 2013, p. 14), 
with a formal record of 1686 in the national records maintained by the responsible Danish government agency (http://www.kulturarv.dk/ fundogfortidsminder). ${ }^{1}$ The majority are represented by finds of single artefacts, but this may result from a lack of further investigation or limited exposure of the underlying land surface. Sites subject to more intensive survey and collection have generated hundreds to thousands of artefacts. Most are in shallow water (c. 2-5 m) and younger than $10,000 \mathrm{cal} \mathrm{BP}(10 \mathrm{ka}){ }^{2}$ mostly Mesolithic or Early Neolithic. Many are the result of reports by sports divers and amateur archaeologists from the 1950s onwards or chance finds by offshore industrial and commercial activity going back to the nineteenth century. Some of the larger assemblages of material represent cultural layers that are still in situ and have remained largely intact following submergence, while others represent material that has been redeposited by marine action during and after submergence. Distinguishing between primary and secondary deposits is a major issue in the interpretation of underwater sites in Denmark (Andersen 2009, p. 13, 2013, p. 29).

Systematic survey began in the early 1970s, with bursts of activity in the 1980s and 1990s. Much of the most detailed survey work concentrated around the shorelines of the island of Fyn and its immediate neighbours (Skaarup 1983, 2001, 2004; Fischer 1993). Systematic excavation took place at a small number of sites, notably at Tybring Vig (Andersen 1980, 1985, 2013), Møllegabet II (Grøn and Skaarup 1993; Skaarup and Grøn 2004), Argus Grund (Fischer 1987) and Ronæs Skov (Andersen 2009), resulting in the development of novel methods of underwater

\footnotetext{
${ }^{1}$ The differences are due to the fact that the higher figures include estimates of the number of sites that should be present along the submerged shorelines of southern Denmark by extrapolation from the density of finds of the same period known from the uplifted shorelines of northern Denmark.

${ }^{2}$ In this chapter, ka (thousands of years ago) is used to mean thousands of calibrated radiocarbon years before present. For conversion to cal BC, subtract 2000 years. For example, $6 \mathrm{ka}$ is equivalent to $6000 \mathrm{cal} \mathrm{BP}$ or $4000 \mathrm{cal}$ $\mathrm{BC}$ and these conventions are used interchangeably throughout the text.
}

excavation and equipment (see Dal 2013 for details).

Another important group of remains on both sides of the Great Belt (Storebælt) was recovered during construction of the road and rail link between Fyn and Zealand (Pedersen et al. 1997).

These sites, with their extraordinary record of organic remains preserved in anaerobic sediments, have dominated the evaluation of the Danish record and remain key sources of information and points of reference (see also Fischer and Vang Petersen 2018 for a summary of key finds).

In addition to archaeological finds, there are also numerous remains of submerged forests, including tree stumps in situ and fallen logs, identified at all depths on the Danish seafloor including the North Sea sector (Fischer 2004). These provide valuable information on changes in shoreline position and rates of sea-level change, targets for closer survey for archaeological sites and the potential for high resolution dating based on dendrochronology (Christensen 1997, 2013; Fischer 1997).

This unusual concentration of finds is the product of many factors:

- A geomorphological and palaeogeographical history that has created extensive shallow and sheltered areas with accumulations of gyttja, a peaty clay conducive to organic preservation

- Ecological and topographic conditions favourable to palaeoeconomies heavily dependent on marine resources and to concentrations of settlement on the shoreline, especially in areas conducive to the trapping of fish and sea mammals during their seasonal migrations

- An abundance of flint sources for making artefacts that are easily visible eroding out of submerged layers on the shallow seabed or along the modern shoreline

- Informed interest amongst sports divers, amateur archaeologists and other members of the public in reporting finds, which intensified in the 1950s with the wider availability of SCUBA equipment

- A relatively long history of systematic investigation by professional archaeologists with 
dive training and experience and the development of new skills and knowledge in underwater exploration and excavation

- A national heritage agency (currently known as the Danish Agency for Culture and Palaces) committed to the recording and management of underwater sites, enshrined in national legislation since 1984

- Recovery of material by industrial activities that go back to the nineteenth century, such as harbour construction, dredging of waterways, commercial extraction of shell, sand and gravel and, in the past two decades, major bridge and tunnel projects across the Danish Straits accompanied by systematic underwater investigation

By common consent, Denmark has acquired a reputation as the 'capital' of underwater Stone Age archaeology, a phenomenon that archaeologists elsewhere look to for standards of best practice and examples of what might be found on other submerged landscapes. A key question is whether this concentration of sites is unique to conditions in Denmark, and more specifically to the region of the Danish Archipelago and the Danish Straits, or can be expected elsewhere, either as visible remains on the seafloor or embedded in deeper sediments. In fact, comparable finds have been found in the adjacent regions of Sweden (Nilsson et al., Chapter 4) and northern Germany (Jöns et al. Chapter 5, this volume) and in other parts of Europe as described elsewhere in this volume; nevertheless, the concentration of material in Denmark is exceptional.

The aim of this chapter is to provide the palaeogeographical and archaeological context for the Danish material, to examine conditions of underwater preservation and visibility, to provide an analysis of finds with illustrations of some of the best-preserved examples, to evaluate the significance of the Danish material in relation to its wider context and the prospects for underwater research elsewhere and to outline some directions for future research.

\subsection{Geographical and Archaeological Setting}

Denmark today has one of the highest ratios of shoreline to land area of any country considered in this volume, with c. $7400 \mathrm{~km}$ of coastline including over 400 named islands, and a land area of c. $44,000 \mathrm{~km}^{2}$ of low relief comprising glacial moraines and lake basins with elevations no higher than $170 \mathrm{~m}$ (Nokkentved et al. 2018). No place on land is more than $52 \mathrm{~km}$ from its nearest coastline. The land comprises the Jutland Peninsula, divided in the north by a stretch of water known as the Limfjord, and an archipelago of closely adjacent islands between Jutland and southern Sweden, the largest of which are Zealand, Fyn, Lolland and Falster, and the more distant eastern outlier of Bornholm (Fig. 3.1).

Together, the inshore waters of the east Jutland Peninsula and the Danish Archipelago define a transitional marine zone between the fully oceanic conditions of the North Sea and the brackish water of the Baltic, connected through a series of sea channels that separate Denmark from Norway and Sweden. These channels become progressively shallower from north-west to south-east, and progressively less saline, and the sea bottom consists of soft sediments of clay, sand and gyttja. To the north, the Skagerrak is a c. $100 \mathrm{~km}$-wide channel, >500 $\mathrm{m}$ deep, an eastward extension of the Norwegian Trench, which remained an open sea channel throughout the Last Glacial period and an insurmountable barrier to human movement. To the south-east, the Kattegat is another wide channel, but much shallower, mostly less than $50 \mathrm{~m}$ bpsl (below present sea level), with an extensive shallow shelf of $<20 \mathrm{~m}$ extending out from the east coast of Jutland. At its southern end, the Kattegat separates into a series of narrow and shallow channels (the Danish Straits), the Little Belt between Jutland and Fyn, the Great Belt between Fyn and Zealand and the Øresund between Zealand and southern Sweden. Here, the seabed is generally less than $20 \mathrm{~m}$ bpsl (Rosentau et al. 2017, Fig. 5.1). These channels, in their turn, open out eastwards into the wider expanses of the western Baltic Sea. 


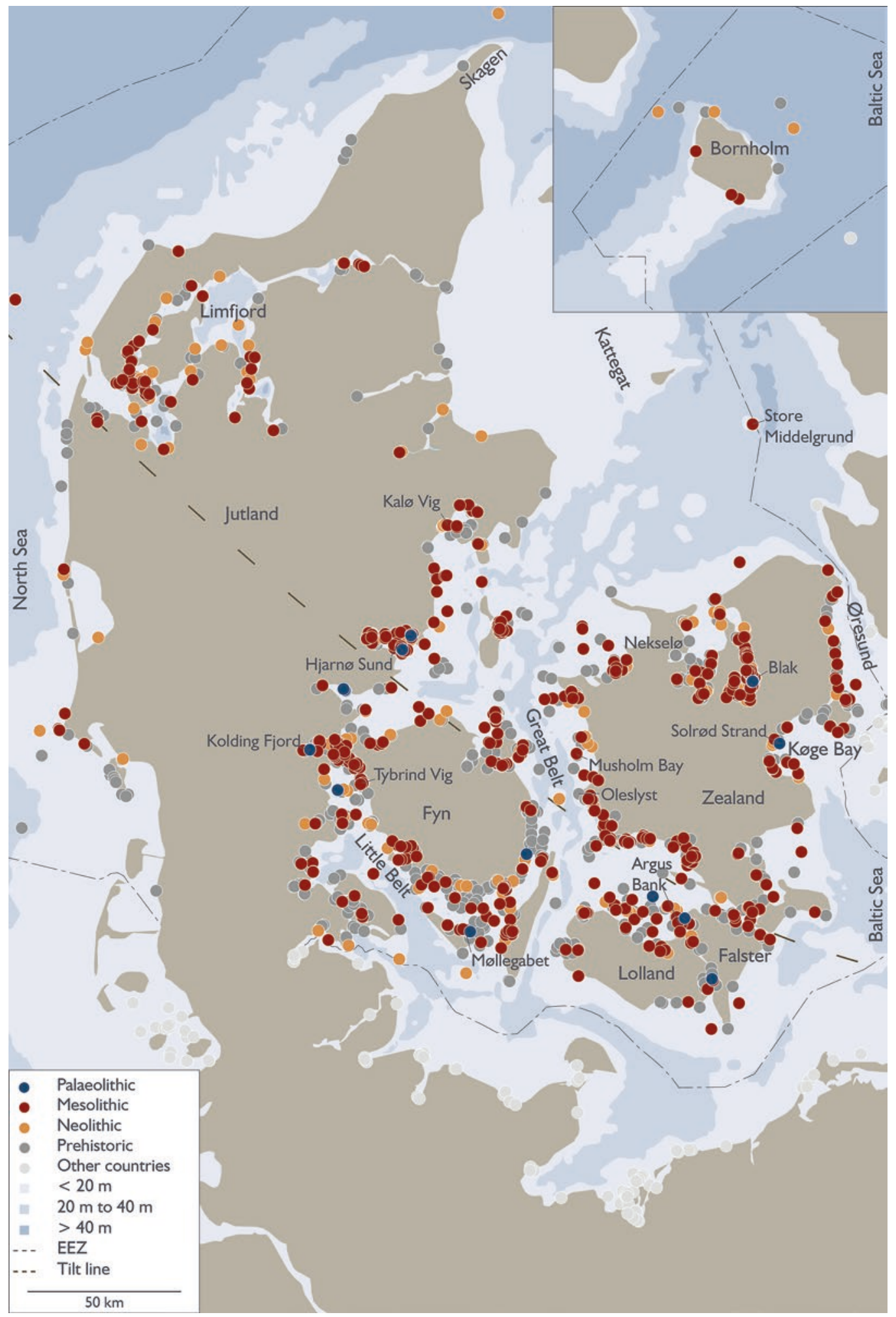

Fig. 3.1 Map of Denmark showing distribution of underwater sites, key names and other places mentioned in the text. Inset shows the island of Bornholm. Site information from the SPLASHCOS Viewer http://splashcos-viewer.eu. Drawing by Moritz Mennenga 


\subsubsection{Archaeological Sequence}

At the LGM at c. $20 \mathrm{ka}$, Denmark was uninhabitable. Much of it was covered by the southern edge of the Scandinavian ice sheet, apart from a strip of land in western Jutland - a barren plain of outwash sands and gravels. The earliest traces of human occupation date from c. $15 \mathrm{ka}$ in southern Jutland and Zealand, after the retreat of the ice front. The sites represent reindeer hunters belonging to the tanged point cultures of northern Europe, successively Hamburgian, Federmesser, Bromme and Ahrensburgian (Table 3.1), and are linked to hunting territories extending across an open tundra landscape with lakes and valleys carved out by glacial action and subsequent channel outflow from the Baltic, which constrained seasonal reindeer migration routes on a northsouth axis from northern Germany to southern Sweden, and perhaps also westwards onto the now-submerged plain of the North Sea (Holm 1991; Vang Petersen and Johansen 1991; Fischer 2004). These tanged point assemblages show similarities over large areas of lowland northern Europe extending westwards across the North Sea Plain to northern Britain, indicating wideranging seasonal movements and long-distance contacts (Momber and Peeters 2017; see also
Jöns et al., Chapter 5, this volume, Bailey et al., Chapter 10, this volume).

These tanged point cultures were succeeded by the Maglemose culture (c. 11-8.4 ka) with new equipment including axes and microlithic arrowheads adapted to the spread of more forested conditions and associated mammalian fauna-principally elk (Alces alces), aurochs (Bos primigenius), red deer (Cervus elaphus), roe deer (Capreolus capreolus) and boar (Sus scrofa ferus). Settlements were located around the edge of lake basins, with evidence of fishing in the form of barbed bone points. Similarities on either side of the North Sea are still apparent in this period. There are hints of contact with the contemporaneous coastline in the form of occasional seal bones in inland settlements (Degerbøl 1943), but no known Maglemose coastal settlements on the modern shoreline, which would still have been some distance inland from the contemporaneous shoreline.

From c. 8.4-7.4 ka, a new type of microlithic arrowhead appeared that defines the Kongemose culture, showing much continuity with the preceding period, but with the appearance for the first time of shoreline settlements and evidence of marine exploitation. This in turn is succeeded by the Ertebølle culture (c. 7.4-6 ka) with its well-

Table 3.1 Chronological chart showing the main archaeological periods and changes in palaeogeography. Chronological boundaries are approximate

\begin{tabular}{|c|c|c|c|c|}
\hline Cal BP & Archaeological period & Archaeological subdivision & Palaeogeographical stage & Cal BC \\
\hline $4400-3700$ & Late Neolithic & & \multirow[t]{10}{*}{ Littorina Sea } & $2400-1700$ \\
\hline $4800-4400$ & \multirow[t]{2}{*}{ Middle Neolithic } & $\begin{array}{l}\text { Single Grave } \\
\text { Pitted Ware }\end{array}$ & & $2800-2400$ \\
\hline $5300-4800$ & & \multirow[t]{2}{*}{ Funnel Beaker } & & $3300-2800$ \\
\hline $5900-5300$ & Early Neolithic & & & $3950-3300$ \\
\hline $6300-5900$ & \multirow[t]{3}{*}{ Late Mesolithic } & Late Ertebølle & & $4300-3950$ \\
\hline $6800-6300$ & & Middle Ertebølle & & $4800-4300$ \\
\hline $7400-6800$ & & Early Ertebølle & & $5400-4800$ \\
\hline $7700-7400$ & \multirow[t]{3}{*}{ Middle Mesolithic } & Late Kongemose & & $5700-5400$ \\
\hline $8000-7700$ & & Middle Kongemose & & $6000-5700$ \\
\hline $8400-8000$ & & Early Kongemose & & $6400-6000$ \\
\hline $9800-8400$ & \multirow[t]{3}{*}{ Early Mesolithic } & \multirow[t]{3}{*}{ Maglemosian } & Initial Littorina Sea & $7800-6400$ \\
\hline 10,700-9800 & & & Ancylus Lake & $8700-7800$ \\
\hline $11,000-10,700$ & & & \multirow[t]{2}{*}{ Yoldia Sea } & $9000-8700$ \\
\hline $11,700-11,000$ & \multirow[t]{4}{*}{ Late Palaeolithic } & \multirow[t]{2}{*}{ Ahrensburgian } & & $9700-9000$ \\
\hline $12,500-11,700$ & & & \multirow[t]{3}{*}{ Baltic Ice Lake } & $10,500-9700$ \\
\hline $14,000-12,500$ & & Bromme/Federmesser & & $12,000-10,500$ \\
\hline $14,700-14,000$ & & Hamburgian & & $12,700-12,000$ \\
\hline
\end{tabular}

Data from Pedersen et al. (1997) and Rosentau et al. (2017) 
known evidence of coastal settlement, large shell mounds (kitchen middens), marine exploitation and new items of material culture including transverse microlithic arrowheads and ceramic vessels alongside evidence of ongoing hunting and gathering on land. From 6 ka, Neolithic settlements appeared with new types of pottery and evidence of farming, most likely involving some degree of population replacement, but with evidence for the continued exploitation of marine resources, especially shell middens, at least in the first 4-500 years.

Taken at face value, this sequence suggests a progressive shift from emphasis on big-game hunting and large territories to a broader spectrum economy including some aquatic resources, to a highly diversified economy with major emphasis on marine resources, smaller territories and permanent settlements and ultimately to replacement by a mixed farming economy. It is tempting to suppose that this sequence indicates intensification associated with population growth and related sociocultural developments. However, this would be to take the evidence at face value without consideration of other variables. Changes in the earlier part of the sequence are clearly related to climatic and vegetational changes associated with de-glaciation, later in the sequence to regionalisation associated with geographical fragmentation by rising sea level, and at the end of the sequence to the introduction of domestic crops and livestock from outside the region. The apparently progressive growth in the number of coastal settlements and importance of marine resources during the Mesolithic period is the main focus of interest in this chapter and needs to be calibrated against the changing configuration and ecology of coastlines and the conditions of site preservation and discovery associated with relative sea-level change.

\subsection{General Conditions of Preservation and Visibility}

Cohen et al. (2017) and Rosentau et al. (2017) set out the general conditions that affect the survival of submerged land forms and archaeological material for the North Sea and the Baltic Sea, respectively. Denmark, because of its location on the boundary between these two basins, has some distinctive patterns of variability in space and time that we examine here. As with all discussions of underwater preservation, we emphasise that local features may also be of great importance and over-ride general conditions in the wider area. These local conditions will be examined more closely later when discussing individual archaeological sites.

\subsubsection{Oceanographic Variables}

Oceanographic variables are of significance in highlighting the distinctiveness of the inner waters of the Danish Archipelago in contrast to the more typical conditions that prevail on North Sea and Atlantic coastlines.

On the exposed western and northern coasts of Jutland facing the North Sea and the Skagerrak, the tidal range is relatively large by Danish standards, being c. $1 \mathrm{~m}$, although this is at the lower end of the spectrum compared to other coastlines of the North Sea and the Atlantic margins (Westley 2017). A coastline of sandy beaches and embayments is protected in places by offshore sand bars, but wave fetch is large, extending without interruption for hundreds of kilometres from the west and north-west, and the coastline is vulnerable to storm erosion (Sistermans and Nieuwenhuis 2018). In the Danish Archipelago and the Limfjord, in contrast, tidal range is c. $10 \mathrm{~cm}$ (though this may be increased by local conditions of wind and currents), and wind fetch may be as little as $1-5 \mathrm{~km}$, resulting in low rates of erosion of the seabed even in shallow water (Rosentau et al. 2017).

During the earlier part of the Littorina Sea period, coinciding with the Late Mesolithic (Table 3.1), there is evidence for greater tidal inflow into the Danish Straits than today and a greater tidal range (Petersen and Rasmussen 1995; Petersen 2013). At about the MesolithicNeolithic transition, conditions appear to have changed, with a reduction in tidal amplitude and salinity and increased rates of sedimentation in 
shallow fjords and estuaries. These changes are relevant to issues of underwater site preservation and visibility, though their timing, causes and consequences are complex (e.g., Lewis et al. 2016) and may have varied according to local circumstances.

\subsubsection{Palaeogeographical Change}

Between the Last Glacial Maximum at $20 \mathrm{ka}$ and the cessation of sea-level rise generated by ice melting at about $5 \mathrm{ka}$, changes in regional geomorphology and palaeogeographical configuration show a complex interplay between ice-retreat, isostatic land adjustment, eustatic sea-level rise and intermittent damming of the Baltic as a freshwater lake (Björck 1995; Rosentau et al. 2017; Astrup 2018) (Figs. 3.2 and 3.3). This has very significant implications for understanding where palaeoshorelines were located at different periods of the archaeological sequence and the con- ditions that have variously favoured or inhibited the preservation and exposure of underwater material.

Initially, rivers drained into the North Sea and later into the Skagerrak as the ice began to retreat (Fig. 3.2a, b). With further ice retreat, the presentday territory of Denmark and southern Sweden opened up as a continuous area of lowland territory that acted as a barrier between a Baltic Basin that filled with glacial meltwater and a marine inlet that occupied the deeper, eastern part of the Kattegat Basin $>40 \mathrm{~m}$ bpsl.

The Baltic remained largely isolated as a freshwater basin, its waters dammed back initially by ice and later by slowly uplifting land rebounding after the removal of ice cover, but with sufficient outflow of water to erode the valleys that now form the Danish Straits (Fig 3.3c). A sea connection was briefly established to the north between the Baltic and the Skagerrak at c. 11.7-10.7 ka, the Yoldia Sea period (Fig. 3.3d). However, the shallow shelf along the east coast of
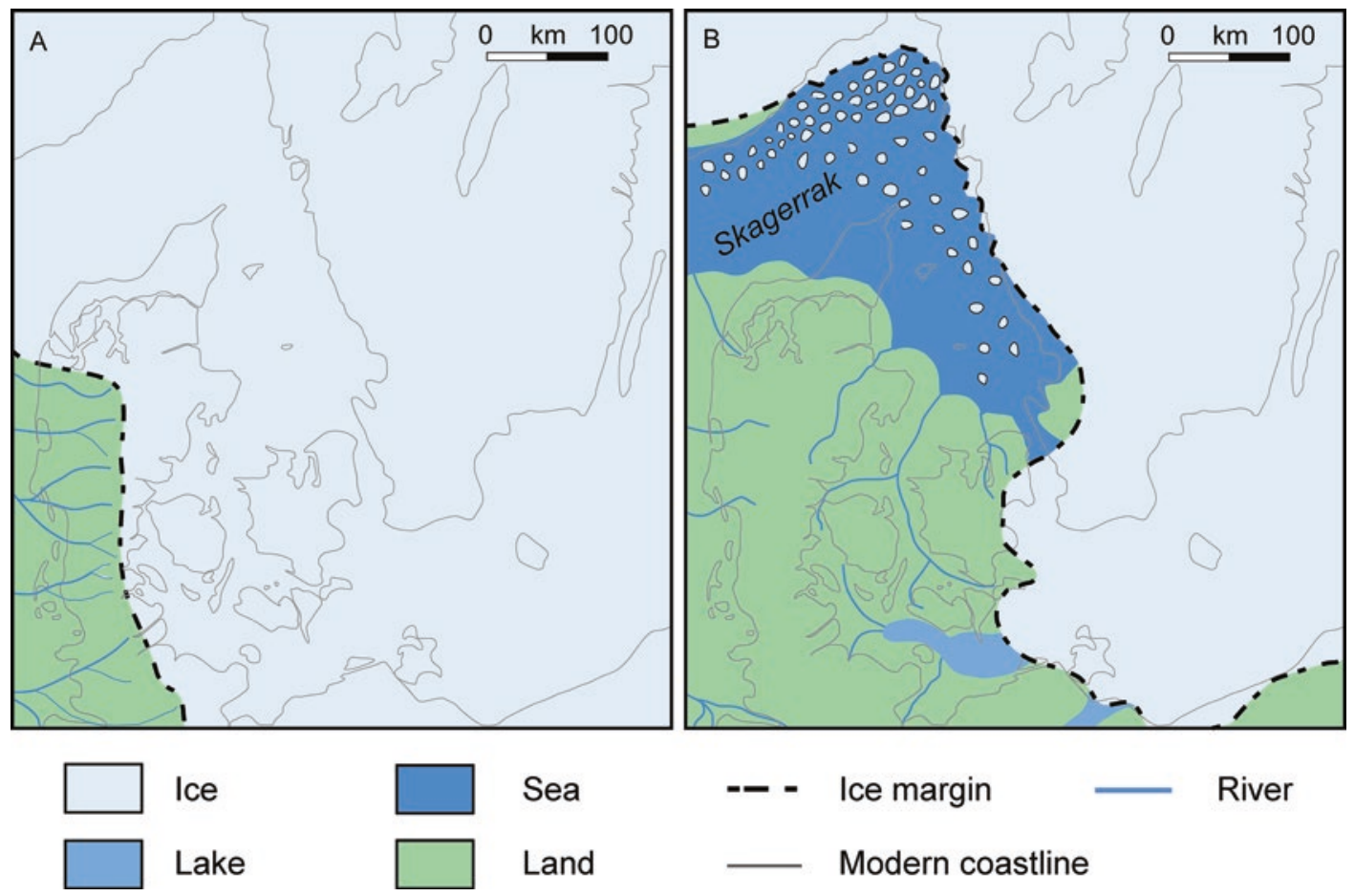

Fig. 3.2 South-west Scandinavia and the south-west Baltic, showing changes in the configuration of land, sea and ice during and immediately after the Last Glacial Maximum: (A) c. 22,000 cal BP; (B) c. 16,000 cal BP. Data from Houmark-Nielsen and Kjær 2003; Rosentau et al. 2017. Drawing by Geoff Bailey 

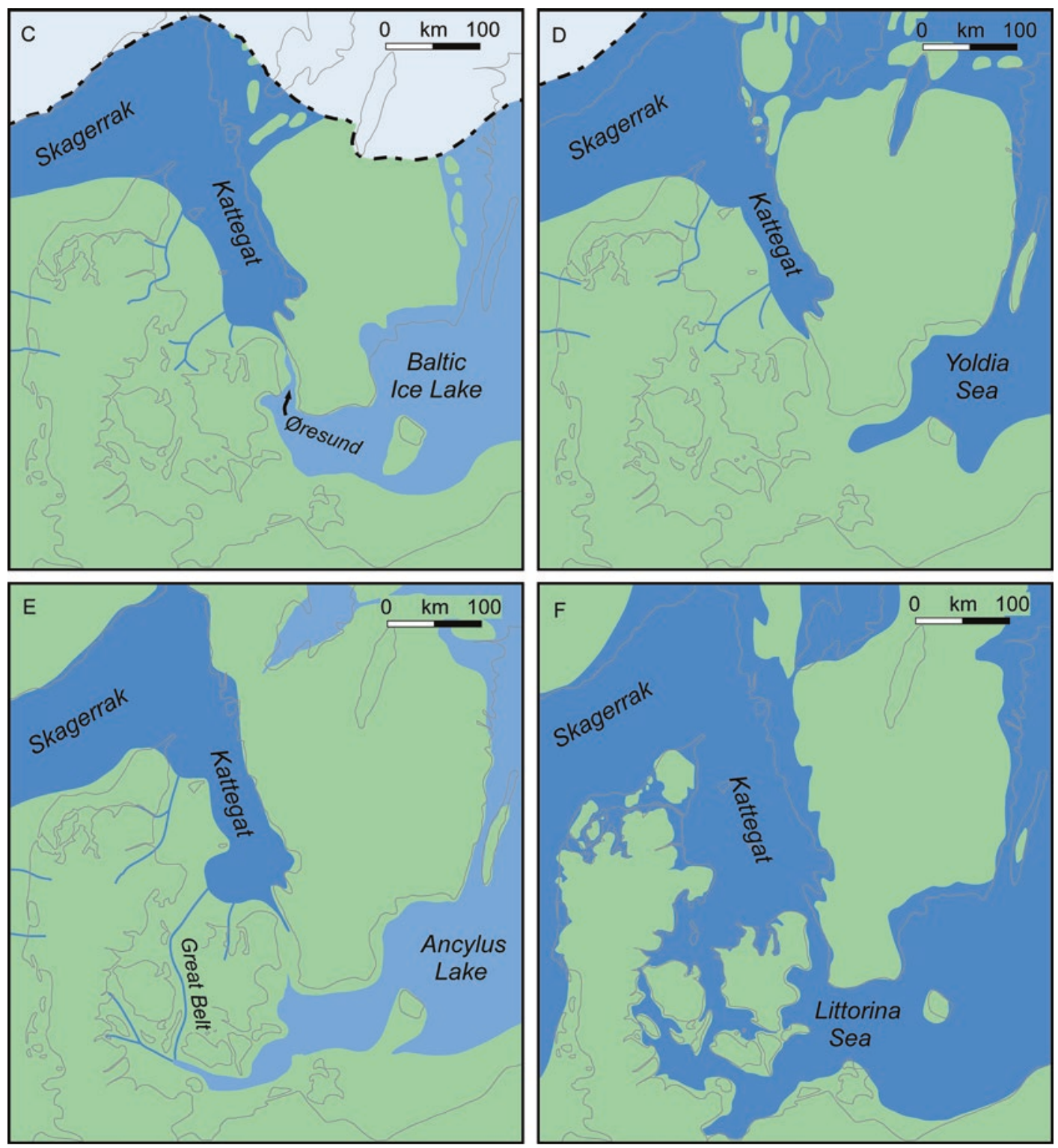

Fig. 3.3 South-west Scandinavia and the south-west Baltic, showing successive stages in the configuration of land, sea, ice and lake basins during the Late Glacial and Postglacial period: (C) c. 14,000 cal BP; (D) c. 11,000 cal BP; (E) c. $10,000 \mathrm{cal} \mathrm{BP}$; F) c. $8500 \mathrm{cal}$ BP. Legend as in Fig. 3 2. Dates and geographical outlines are approximate. Data from Björck (1995), Jensen et al. (1997), Mathiasen (1997), Uścinowicz (2003, 2014), Påsse and Andersson (2005), Rosentau et al. (2017). Drawing by Geoff Bailey

Jutland and the area of the Danish Straits continued to form a continuous lowland area of limited relief extending into southern Sweden, dotted with small lake basins and traversed by river valleys formed by the outflow from the Baltic (Fig. 3.3e).
From shortly after about $10 \mathrm{ka}$ onwards, a fully marine connection was established through the Danish Straits-the Littorina Sea period (Table 3.1). Sea level rose from about $-30 \mathrm{~m}$ to near the present level in a matter of c. 1000 years between c. 9 and $8 \mathrm{ka}$ with a slower rise towards 
the present level thereafter (Christensen 1995). Between about 7.5 and $5.5 \mathrm{ka}$, the final rise of sea level took place, with minor fluctuations that created a series of four high-sea-level stands, separated by periods of minor sea-level regression. These are the so-called Littorina shorelines. They most likely represent episodes of isostatic uplift interacting with a final, slow and steady rise of eustatic sea level from $-2 \mathrm{~m}$ to reach the present sea level at about $5 \mathrm{ka}$, rather than eustatic sealevel fluctuations (Gehrels et al. 2006). At the time of the highest Littorina sea level, northeastern Denmark was fragmented into an archipelago with broader openings between the North Sea, the Skagerrak and the Kattegat and a stronger inflow of water from the North Sea (Fig. 3.3f).

After $5 \mathrm{ka}$, isostatic effects continued, with uplift in the north-east and submergence in the south-west. The boundary between uplift and submergence runs from south-east to north-west (Fig. 3.1), and the Littorina shorelines show progressively higher elevations and earlier dates as one moves north, with the highest shorelines in northern Jutland at $12 \mathrm{~m}$ apsl (above present sea level) with dates of c. $7.2 \mathrm{ka}$ and progressive submergence in the south to depths of $-8 \mathrm{~m}$ (Christensen 1995; Christensen and Nielsen 2008; Astrup 2018).

For the earlier part of the sequence, most of the area between Denmark and Sweden was above the contemporaneous sea level, and nowsubmerged sites are likely to be hunting stations for monitoring or trapping animals, or settlements along rivers or lake edges. Once the Littorina Sea entered the Danish Straits, marine shorelines would have been present from the later Maglemose or early Kongemose period onwards at depths dependent on the local interaction between sea-level rise and isostatic adjustment. Shorelines of the Maglemose period are everywhere submerged below the present-day sea level or eroded away. Shorelines of the Kongemose period are mostly submerged or covered by later sediments, being present above sea level only in north-eastern Denmark (Fischer 1993, p. 60), while shorelines of the Ertebølle period are at or above modern sea level in north-eastern Denmark and submerged in areas to the south-west.
The main effect of isostasy is that shorelines of the same age are now at a relatively higher elevation in the north than the south, an effect best illustrated in the Ertebølle period. Many hundreds of Ertebølle coastal sites are located on raised shorelines in the Limfjord region of northern Jutland, the east coast of Jutland and the northern coasts of Fyn and Zealand. Andersen (2000, p. 362) refers to over 500 Ertebølle shell mounds in this region, with perhaps a comparable number of contemporaneous coastal sites that are not shell middens. To the south, in the coastal regions that have undergone submergence, there is a comparable number of sites that are now under water. Underwater shell midden deposits, however, are very rare. It is the effect of this submergence that is key to understanding the abundance, character, state of preservation and visibility of underwater sites in the central and southern region of the Danish Archipelago.

\subsection{Archaeological Analysis}

Currently there are 1699 archaeological finds recorded in the SPLASHCOS Viewer (http:// splashcos-viewer.eu/), of which 1686 are registered in the records of the Danish Agency for Culture and Palaces (http://www.kulturarv.dk/ fundogfortidsminder/). ${ }^{3}$

${ }^{3}$ This is less than the total number referred to in the published literature. In 2004, Fischer referred to 2003 prehistoric sites and noted that this number of finds was probably 'just a few percent of what is actually existing in the national sea territory' (Fischer 2004, p. 23). It is clear that we are dealing here with a minimum number of finds, but equally that a great many find spots are single artefacts or material that has been disturbed or re-deposited by marine erosion. The analysis in this section assumes that the available records are broadly representative. The online records of the Danish Agency are in Danish and give information on location, brief details of finds, their history of discovery and references to the published literature where available. It is also important to note that many prehistoric sites were located around shallow bays that subsequently silted up and were drained to create modern farm land. These sites are not, strictly-speaking, 'underwater' but they include material that was deposited under water or later became inundated by sea-level change, and we include reference to some of them, notably from the Halsskov Fjord discussed later in this chapter. 
The great majority, 1307 (79\%), are recorded only as single finds, while sites indicating evidence of settlement comprise 293 records (17\%) (Table 3.1). A 'settlement' in this context means clear evidence of human occupation and artefact production, usually involving a considerable density of cultural material (Fischer 1993, p. 72). This may take the form of features such as a hearth, the presence of debitage from toolworking, burnt flint and abandoned tools, remains of stationary fish weirs and graves as indicated by the presence of human bones. Artefacts by themselves, even in considerable quantity, are not necessarily a sufficient indication of in situ activity or a settlement with dwelling structures, since they may have been redeposited by marine action or represent more ephemeral activities or specialised functions. Categorisation in many cases is a matter of subjective judgement and the experience of the archaeological observer. In cases of doubt, material is placed in the category of unstratified material (12 records, $0.7 \%$ ).

Conversely, the recording of a single find does not rule out the presence of a settlement and indicates only what was observable on or recovered from the surface of the seabed or along the modern coastline. The quantity of material recovered is also in part a function of the time spent examining a given locality and the conditions of visibility, especially when diver inspection is involved. It is also clear from the general literature (e.g. Fischer 2004, p. 28; Fischer and Vang Petersen 2018) that material recorded as single finds may include items accidentally lost at sea such as amber pendants, fish hooks and harpoon heads as well as items discarded on a nowsubmerged land surface or archaeological settlement.

Two other categories to note are votive deposits, some 12 records $(0.7 \%)$, mostly of Neolithic or Bronze Age date, but including at least one Ertebølle example, identified by the presence of artefacts presumed to be of great value because of their careful workmanship such as bifacially worked flint daggers and battle axes, and miscellaneous finds ( 26 records, $1.5 \%$ ). The latter include isolated remains of fish traps, large stone objects of uncertain function or indeterminate artefacts.
Many sites with settlement remains were discovered by Fischer's 'fishing-site model' (Fischer and Sørensen 1983; Fischer 1993, 1995, 2007). This is a predictive model based on the observation that a number of already-discovered sites were located in topographic conditions ideal for trapping fish during their seasonal migrations: at the mouths of stream inlets, at the entrance to semi-enclosed shallow bays or on the end of small peninsulas jutting out into a marine channel, especially where a small offshore island funnelled fish movements into a narrow strait between the island and the facing shoreline. Use of bathymetric contours supplemented by simple acoustic surveys to identify similar topographic conditions on submerged palaeoshorelines resulted in a high degree of success in the location of new sites.

It is clear from the map (Fig. 3.1) and the data in the SPLASHCOS Viewer that the great majority of finds (1437) are from the protected shorelines of the inner Danish Archipelago, including the sheltered coastlines of east Jutland from Aarhus Bay southwards and the coastlines of the major islands, especially southern Fyn and southern Zealand. The next largest category (155) is in the Limfjord region of northern Jutland, which would have offered similar protected conditions during the Littorina Sea period. Just 50 sites are recorded from the more exposed coastlines of the North Sea, the Skagerrak and the Kattegat, with a small number at some distance offshore and at depth. The latter include a pressure flaker made from red deer antler of typical Maglemosian type from the Dogger Bank some $250 \mathrm{~km}$ west of the Danish coastline (Fig. 3.4).

In terms of chronology and disregarding the 805 records that can only be identified as 'prehistoric', by far the largest number of finds are Mesolithic in date, 676 records (39.8\%), followed by 122 Neolithic finds, a smaller number (39) that may be Mesolithic or Neolithic, 45 Bronze Age and 15 Late Palaeolithic records (Table 3.2).

The earliest underwater archaeological finds currently known from Danish waters are worked reindeer bones recovered from Køge Bay in east Zealand, one of which, from Solrød Strand, is 
Fig. 3.4 A pressure flaker made from red deer antler, dredged up from a depth of 30-40 m on the Dogger Bank some $250 \mathrm{~km}$ west of the Danish coastline. This specimen is typical of the younger Maglemose period, a date confirmed by radiocarbon dating of the artefact itself to $\mathrm{c}$. 7040-6700 cal BC (Andersen 2005). Scale in $\mathrm{cm}$. Photo courtesy of Moesgaard Museum Photography Department

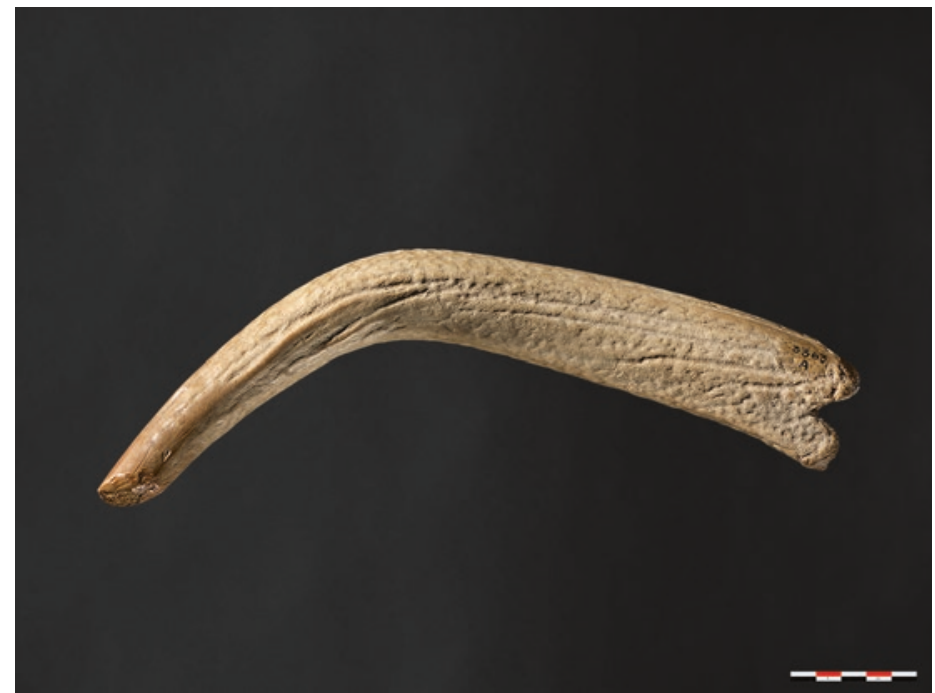

Table 3.2 Distribution of underwater finds by type of site and period. Miscellaneous other includes remains of fish weirs, isolated ground stone objects and other indeterminate artefacts or remains of structures

\begin{tabular}{|c|c|c|c|c|c|c|c|c|}
\hline \multirow[b]{2}{*}{ Types of sites } & \multirow{2}{*}{$\begin{array}{l}\text { Late } \\
\text { Palaeolithic }\end{array}$} & \multirow[b]{2}{*}{ Mesolithic } & \multirow{2}{*}{$\begin{array}{l}\text { Mesolithic- } \\
\text { Neolithic }\end{array}$} & \multirow[b]{2}{*}{ Neolithic } & \multirow{2}{*}{$\begin{array}{l}\text { Bronze } \\
\text { Age }\end{array}$} & \multirow{2}{*}{$\begin{array}{l}\text { Indeterminate } \\
\text { Prehistoric }\end{array}$} & \multicolumn{2}{|l|}{ Total } \\
\hline & & & & & & & $\mathbf{N}$ & $\%$ \\
\hline $\begin{array}{l}\text { In situ cultural } \\
\text { features settlement } \\
\text { data }\end{array}$ & - & 160 & 19 & 6 & 2 & 113 & 300 & 17.6 \\
\hline $\begin{array}{l}\text { Unstratified } \\
\text { material multiple } \\
\text { finds }\end{array}$ & 2 & 2 & 1 & - & - & 7 & 12 & 0.7 \\
\hline $\begin{array}{l}\text { Graves (human } \\
\text { bone) }\end{array}$ & - & 14 & - & 2 & 4 & 29 & 49 & 2.9 \\
\hline $\begin{array}{l}\text { Single unstratified } \\
\text { find }\end{array}$ & 12 & 496 & 19 & 107 & 27 & 645 & 1306 & 76.6 \\
\hline Votive deposits & - & 2 & - & 4 & 3 & 3 & 12 & 0.7 \\
\hline $\begin{array}{l}\text { Miscellaneous } \\
\text { other }\end{array}$ & 1 & 9 & - & 3 & 9 & 5 & 27 & 1.5 \\
\hline Total N & 15 & 683 & 39 & 122 & 45 & 802 & 1706 & 100 \\
\hline$\%$ & 0.9 & 40.0 & 2.3 & 7.2 & 2.6 & 47.0 & & \\
\hline $\begin{array}{l}\text { Presence of } \\
\text { organics (wood } \\
\text { and/or bone) }\end{array}$ & 3 & 72 & 4 & 10 & 3 & 54 & 146 & 8.6 \\
\hline
\end{tabular}

Data from the SPLASHCOS Viewer at http://splashcos-viewer.eu, and from Danish government records at http://www. kulturarv.dk/fundogfortidsminder

dated at $14 \mathrm{ka}$ (Vang Petersen and Johansen 1991, p. 36, endnote 28). These were found in sand and gravel deposits at 6-10 $\mathrm{m}$ bpsl near the outflow at the western end of the ice-dammed Baltic Lake and are most plausibly explained as evidence for the use of the local topography to ambush animals during their seasonal migrations.
The next earliest sites are broadly labelled as Early Mesolithic, generally associated with the Maglemose period. However, there are very few that fall certainly within this period, and these only towards the end, namely, Svalerumpen on the east coast of Zealand facing the Øresund Strait, with a single flint tool, a small number of 
animal bones and a radiocarbon date of $8225 \pm 95$ (Fischer 1993; http://www.kulturarv.dk/fundogfortidsminder/Lokalitet/164010/), equivalent to c. 9.5-9.1 ka (7400-7100 cal BC; see Table 3.1), and sites in Aarhus Bay, Jutland, notably Fløjstrup Skov, with typical microliths of the Maglemose tradition and radiocarbon dates ranging from 7200 to $6300 \mathrm{cal} \mathrm{BC}$, most probably indicating a mixture of artefacts from different periods (Dencker and Jensen 2000; Astrup 2018). Material of similar date has been found on the Swedish side of the Øresund indicating settlements on or close to the shoreline at a time when seawater had entered the northern Øresund but before a marine connection had been established to the Baltic Basin (Larsson 2017; Nilsson et al., Chapter 4, this volume).

The other Early Mesolithic sites, notably the settlement of Musholm Bay in the Great Belt (Fischer and Malm 1997), Kalø Vig on the east coast of Jutland (Fischer 2007), and Blak in Roskilde Fjord (Sørensen 2017), all of which are radiocarbon-dated, lie on the boundary of the Maglemose and early Kongemose periods associated with the onset of the Littorina period, the entry of seawater into the Kattegat and the Danish Straits, and the establishment of a marine connection with the Baltic. From this time onwards, sea level rose rapidly. Sites of successively later periods occur at shallower depths and provide a precise measure of the rate of sea-level rise and the changing configuration of the coastline. At Musholm Bay, for example, an early Kongemose settlement originally located on the contemporaneous shoreline is now at a depth of $-8 \mathrm{~m}$ and $2.5 \mathrm{~km}$ distant from the present shoreline. In little more than 1000 years, by the Middle Ertebølle period, sea level was within half a metre of the present level, and the shoreline had retreated to about its present position. The relationship between the age of coastal archaeological sites and sea-level depth can, of course, be reversed, and inspection of bathymetric charts used to good effect both to reconstruct coastal topography and shoreline configuration at different periods and to predict the location of new sites taking into account the most favourable locations for trapping fish (Fischer 1993, 1997).
Table 3.3 Distribution of underwater finds by archaeological period and time duration in thousands of years (kyr)

\begin{tabular}{l|l|l|l}
\hline $\begin{array}{l}\text { Archaeological } \\
\text { Period }\end{array}$ & $\begin{array}{l}\text { Number of } \\
\text { Recorded } \\
\text { Finds }\end{array}$ & $\begin{array}{l}\text { Duration } \\
\text { kyr }\end{array}$ & $\begin{array}{l}\text { Recorded } \\
\text { finds per kyr }\end{array}$ \\
\hline Neolithic & 159 & 2.2 & 72 \\
\hline $\begin{array}{l}\text { Late } \\
\text { Mesolithic }\end{array}$ & 488 & 1.5 & 325 \\
\hline $\begin{array}{l}\text { Middle } \\
\text { Mesolithic }\end{array}$ & 95 & 1.0 & 95 \\
\hline $\begin{array}{l}\text { Early } \\
\text { Mesolithic }\end{array}$ & 22 & 2.6 & 8 \\
\hline $\begin{array}{l}\text { Late } \\
\text { Palaeolithic }\end{array}$ & 15 & 3.7 & 0.2 \\
\hline
\end{tabular}

Data from http://splashcos-viewer.eu

The number of dateable underwater finds shows an exponential increase from the Late Palaeolithic period through the Early and Middle Mesolithic period, reaching a maximum in the Late Mesolithic (Ertebølle) period, and reducing again in the Neolithic period (Table 3.3; Fig. 3.3). The peak in the Ertebølle period most likely represents, in part, the fact that underwater sites in this period are in shallow water where they are easily discoverable from material eroding out in shallow water or along the modern shoreline, compared to the more deeply submerged sites of earlier periods. The reduction in the Neolithic period may reflect the difficulty of distinguishing on typological grounds between Ertebølle and Neolithic artefacts from isolated finds and also the fact that more shorelines and coastal settlements of this period are above present sea level and therefore not represented in the statistics for underwater finds in Table 3.3.

\subsection{Underwater Settlements}

According to Table 3.2, there are some 160 Mesolithic site records with evidence of settlement activity, namely, evidence of a cultural layer with indications of in situ activity. However, this number should be treated with caution; very few of these have been excavated and the nature of the activities represented and the question of whether they are genuinely in primary position as opposed to materials redeposited by marine 
action remains uncertain in many cases. The small number of sites that have been extensively excavated provide important information on the quality of the evidence that has survived and insights into the variable conditions of preservation at different locations, and they are examined below.

\subsubsection{Tybrind Vig}

This is the most intensively investigated underwater site in Denmark, excavated over a 10-year period from 1978 to 1987 (Andersen 1980, 1985, 2013; Malm 1995) It is one of five submerged settlements within a $10 \mathrm{~km}$ radius on both sides of the Little Belt, the others being Kolding Fjord, Guds $\varnothing$ Vig, Helligkilde and Ronæs Skov (Fig. 3.5). At Tybrind Vig itself, there are, in fact, four closely co-located settlements with in situ or partially in situ material, found at depths ranging from -5 to $-2.5 \mathrm{~m}$ below present sea level (Fig. 3.6). Three settlements are on a sheltered south-west facing shoreline at the mouth of what would originally have been an almost totally enclosed and shallow bay. They are successively shallower and younger deposits representing the landward movement of the shoreline with sealevel rise. The fourth is on an exposed beach ridge on the seaward-facing spit of land on the opposite side of the bay mouth, and represents a different type of site, most likely one with a specialised function. In addition, there are five other locations nearby with redeposited artefacts.

None of these sites represents a completely intact settlement. In all cases the original dryland area of settlement where domestic activities and burials were concentrated has been largely eroded away, leaving only traces of the original land surface and its material remains, or redeposited materials that have been washed out from their original place of deposition. What remains in situ is the dump area just offshore of the main settlement area, where many of the by-products of daily life were originally thrown away, or where material remains were abandoned in situ, representing activities originally located offshore such as fish weirs extending out from the shoreline, or logboats.

Together, these sites represent a cumulative palimpsest of activities representing repeated use of the area and most probably year-round settle-
Fig. 3.5 Map of the Little Belt, showing the position of Tybrind Vig and Ronæs Skov. The three other sites shown are also submerged and contemporaneous with the other two. Like Ronæs Skov, they yielded assemblages with harpoons, sea mammal bones and ceramic blubber lamps. This and their locations suggest that they were optimally positioned to hunt porpoises during their seasonal migrations through the Little Belt by diverting them into narrow side fjords. After Andersen 2013, Figs 7.1 and 7.2 , redrawn by Geoff Bailey

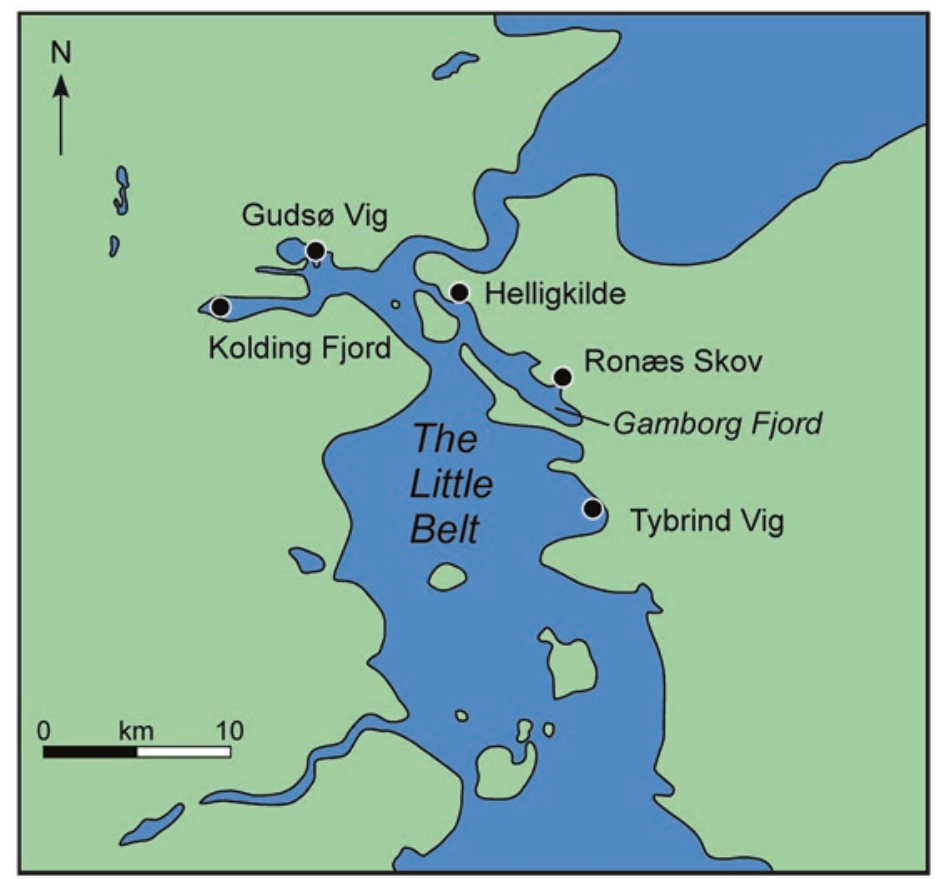




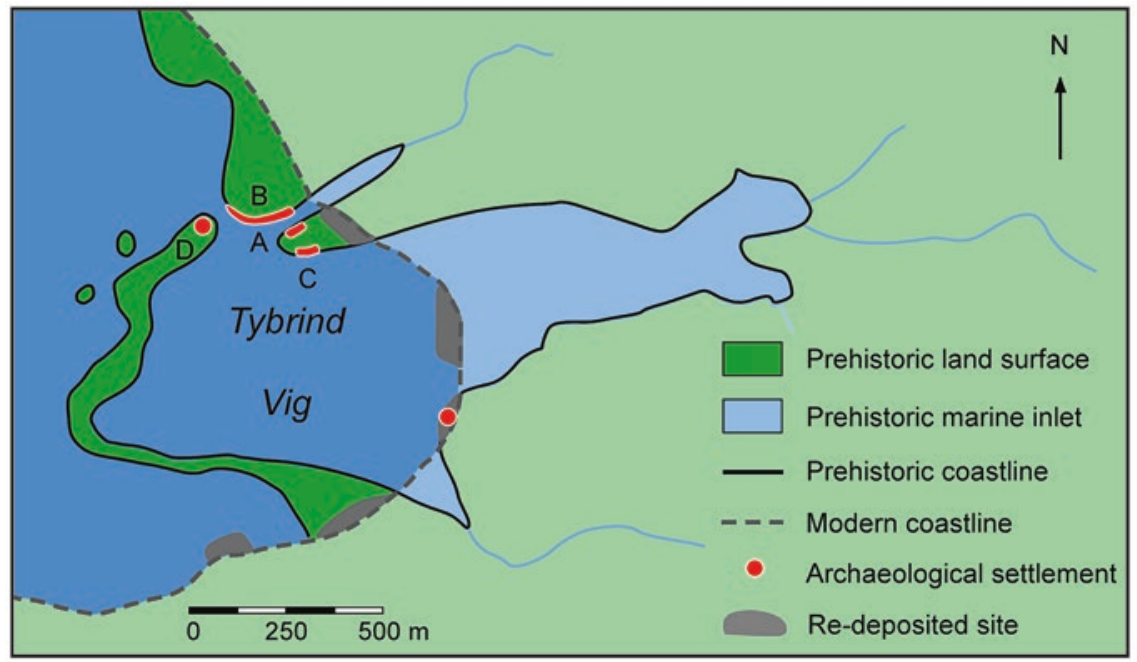

Fig. 3.6 The Tybrind Vig Cove showing the location of archaeological sites and the contemporaneous coastline. After Andersen 2013, Fig. 1.6, redrawn by Geoff Bailey

ment throughout a 1400-year-period between 7.4 and $6 \mathrm{ka}$ (5400-4000 cal BC), equivalent to almost the full span of the Ertebølle period After $6 \mathrm{ka}$, activities ceased, and sea level continued to rise by a further $2-2.5 \mathrm{~m}$ because of isostatic submergence; indeed, this additional sea-level rise may have been a significant factor causing the abandonment of the sites by inundating the spit of land that had previously created the enclosed bay with its topographic advantages for trapping fish and creating shelter. On the plus side from an archaeological point of view, this additional sealevel rise has ensured that many of the archaeological materials have remained permanently submerged in anaerobic conditions since the time of deposition, significantly contributing to their preservation.

The largest site, and also the latest in date, is site B (Figs. 3.6 and 3.7). Here, the original dryland settlement area on the shoreward side, judging from the concentration of stone artefacts, covered some $2600 \mathrm{~m}^{2}$, forming an elongated outline $20 \mathrm{~m}$ wide and extending for about $130 \mathrm{~m}$ along the shore, a form typical of Ertebølle sites elsewhere including those known from uplifted shorelines in northern Denmark. Only two burials were recovered from this dry-land area, one a burial of a young woman and a child (Fig. 3.8), the other a grave with two adults. Both burials are radiocarbon dated to the Early Ertebølle and therefore belong to an earlier phase of settlement than the rest of the material discussed below. Other material had been eroded or washed away. Excavation concentrated on the marine deposits, and trenches extending over a total of $192 \mathrm{~m}^{2}$ were excavated, representing about $10 \%$ of the total marine refuse area (estimated at 1500$2600 \mathrm{~m}^{2}$ ). The material recovered includes objects originally dumped here at the time of settlement, material subsequently eroded out from the dry-land area and redeposited, and in situ remains of fish weirs, logboats and other offshore activities.

Notwithstanding the emphasis of excavation on the dump area, the full range of material culture associated with the Late Ertebølle is represented, including a flint technology of blades, flaked axes and transverse microliths (some 431 items), worked bone and antler (302) and potsherds (825) all from pointed-base vessels. The number of flints is relatively small compared to other Ertebølle sites, but that may reflect the fact that many more were discarded on dry land. Conversely the range of bone and antler artefacts is greater than usual, including axe heads and shafts shaped from red deer antler, a small num- 


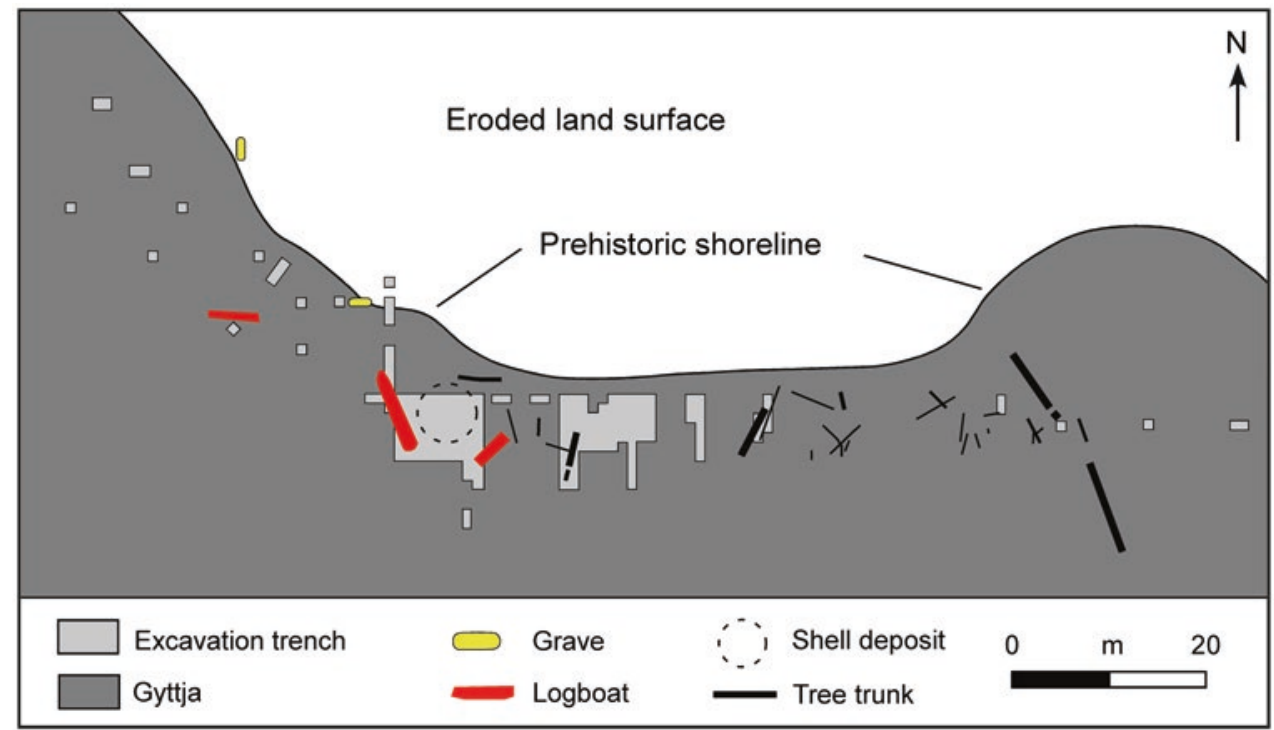

Fig. 3.7 The plan of Tybrind Vig showing the layout of the excavation trenches and other features. After Andersen 2013, Fig 1.10, redrawn by Geoff Bailey

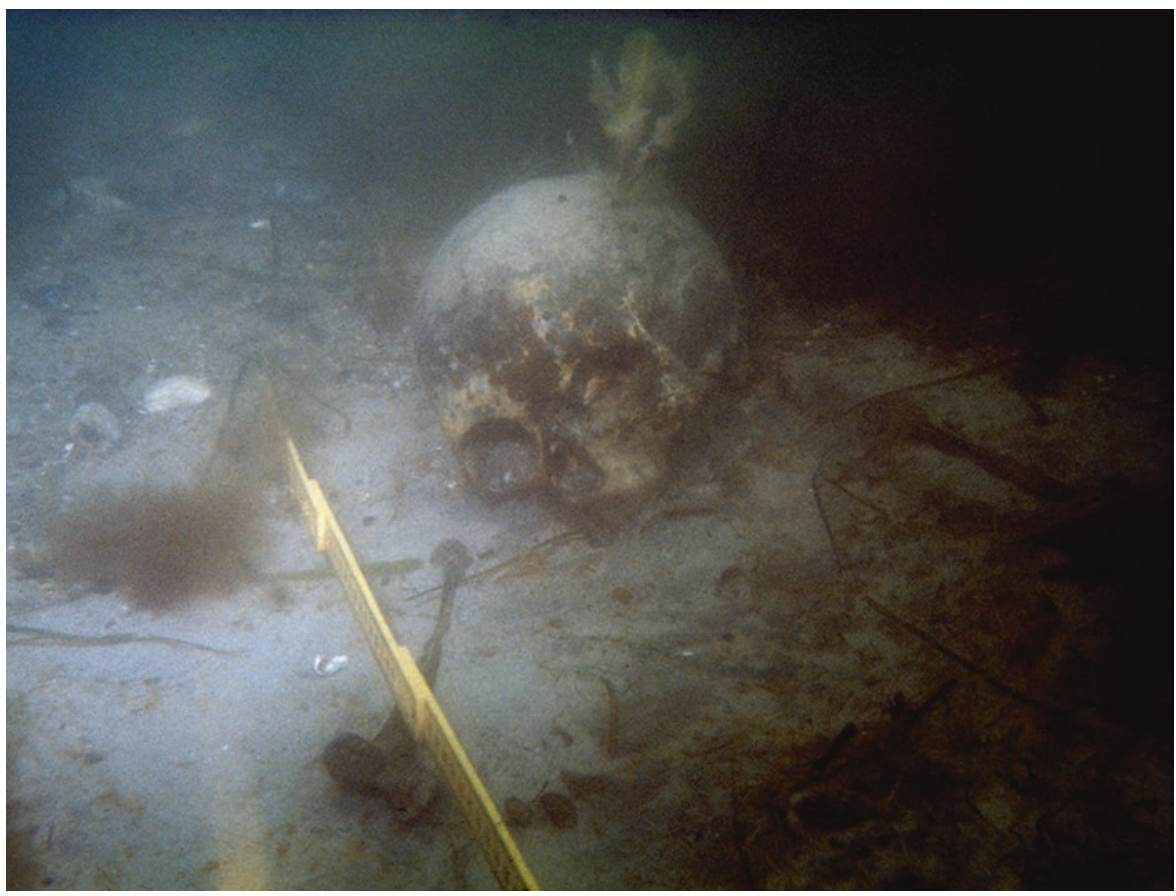

Fig. 3.8 Tybrind Vig burial of a young woman, 14-16 years of age, in situ on the seabed and partially exposed by marine erosion before excavation, showing the skull and bones of the upper arms. The skeleton was fully extended in a shallow grave. Also present were the partial remains of an infant 0-3 months of age. Photo by Hans Dal, courtesy of Moesgaard Museum Photography Department 
ber with incised geometric decoration, bone fishhooks, bone points, red deer and boar tooth ornaments and knives made from boar tusks.

What makes this site unusual, however, is the remarkable preservation of wood and other organic materials such as uncharred plant remains, cordage and textile fragments. The wooden artefacts amount to over 500 specimens including pieces of split timber and wood chips produced during implement manufacture. The largest number are some 250 rods of hazel (Corylus avellana) at least $2 \mathrm{~m}$ in length with a sharpened tip, representing the remains of fish weirs. Their uniform dimensions indicate systematic coppicing of hazel. A small number (48) are thick poles (4-8 $\mathrm{cm}$ diameter) presumed to be the upright supports, confirmed by the finds of several in vertical position, and the remainder are thinner branches or withies presumed to be the horizontal members. Other artefacts include 67 ash shafts (Fraxinus excelsior) up to $2 \mathrm{~m}$ long used as spear shafts, 6 wooden axe handles (Figs. 3.9 and 3.10)

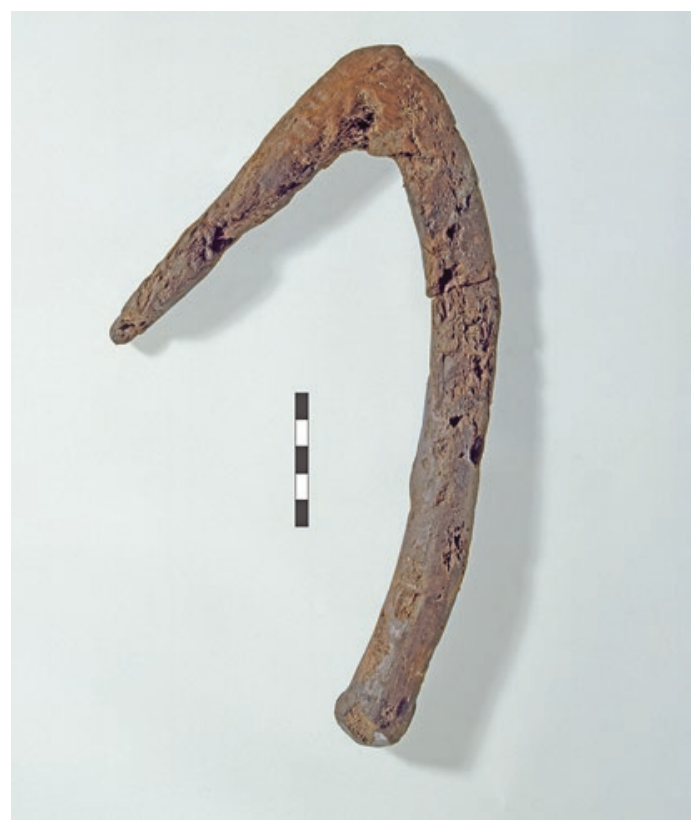

Fig. 3.9 Axe handle from Tybrind Vig made of Pomoideae wood. The base is shaped to fit in the hand. At the other end, the wood is tapered and shaped to mount a flint chisel on the under surface. See also Andersen (2013, p. 131). Scale in $\mathrm{cm}$. Photo courtesy of Moesgaard Museum Photography Department and 20 bows of different types made of elm wood (Ulmus sp.) (Fig. 3.11). Fishing equipment includes 67 leister prongs (Fig. 3.12) and the fragment of a wicker fish trap made from woven alder withies (Alnus glutinosa) (Fig. 3.13). This emphasis on fishing is reinforced by the discovery of many fish hooks made from animal bone. The inventory of wooden artefacts is completed by an almost intact dugout canoe $9.5 \mathrm{~m}$ in length and large parts of at least three other canoes, all made of lime wood (Tilia sp.), and some 14 paddles or paddle fragments of different shapes made of ash wood, including examples with geometric decoration and coloured inlays.

Other organic materials include 33 pieces of twisted cord made from plant fibres (Fig. 3.14), 14 pieces of textile (Fig. 3.15), 6 pieces of rope and 11 pieces of fibrous bark material mostly of

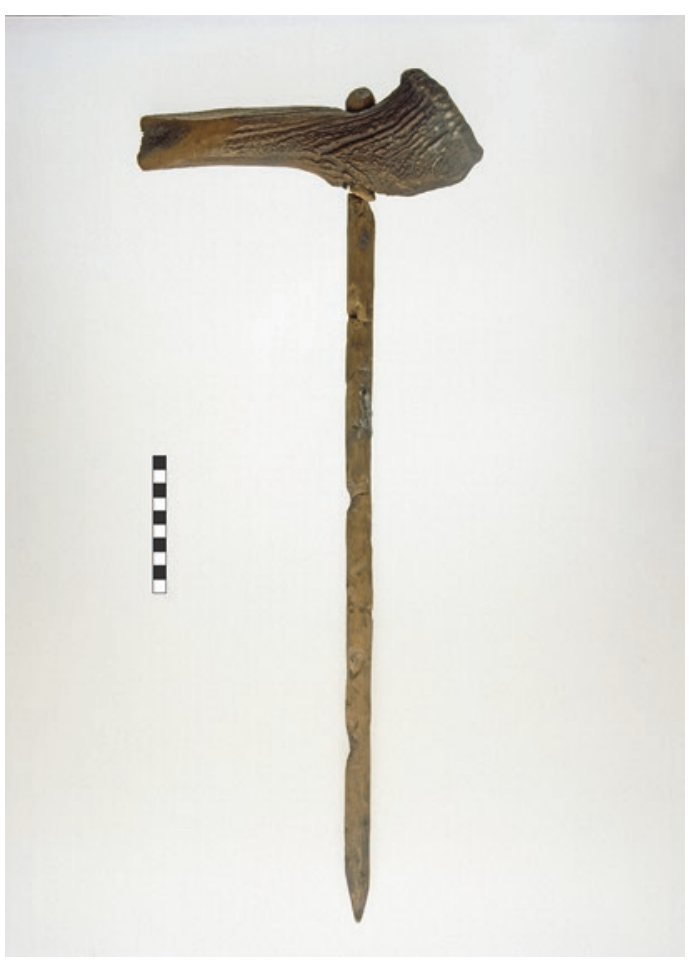

Fig. 3.10 Shaft-hole axe made of red deer antler at Tybrind Vig with a fully preserved wooden handle made from a straight hazel rod just under $2 \mathrm{~cm}$ in diameter. Observe that the shaft terminates in a tongue-shaped point, which might indicate a function as a digging stick. Scale in $\mathrm{cm}$. Photo courtesy of Moesgaard Museum Photography Department 


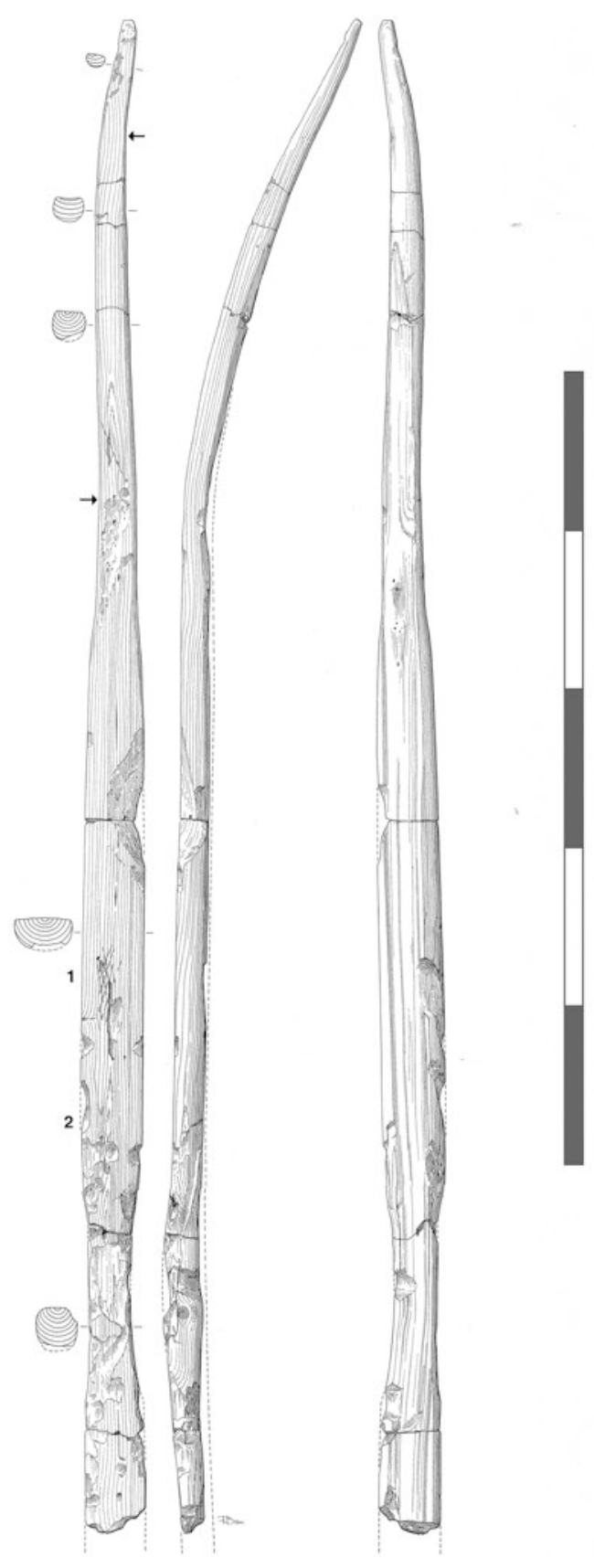

Fig. 3.11 Bow made of elm wood. It is narrowed at the waist to form a grip and has been broken just below. This is the most common type of bow with ten examples at Tybrind Vig with more than half of the bow intact. The original length would have been 1.5-1.6 m. Scale in 10 -cm units. Drawing by F. Bau, courtesy of Moesgaard Museum Photography Department
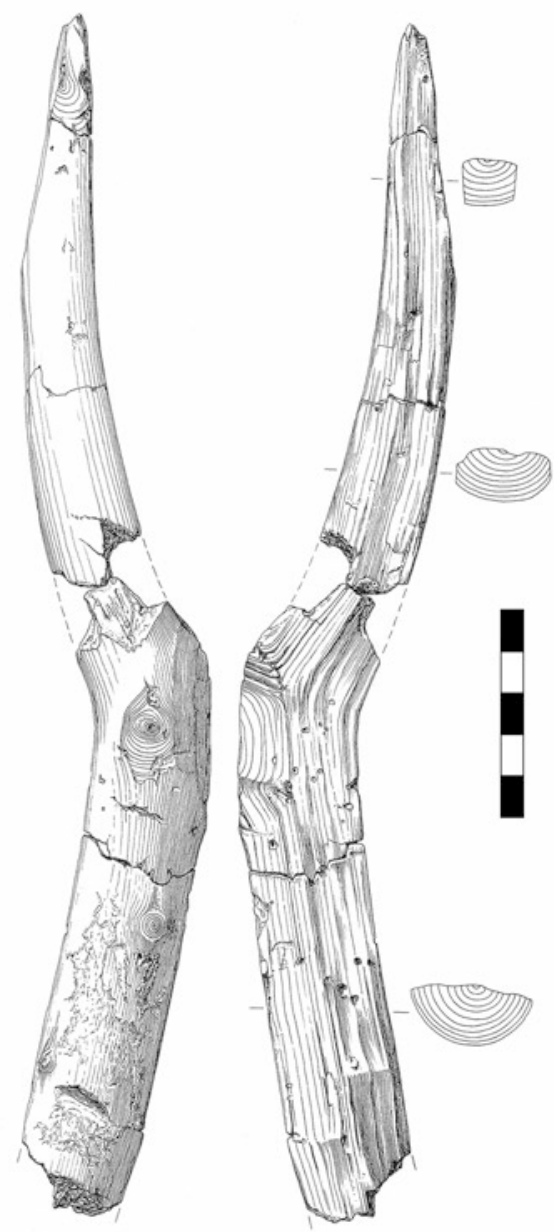

Fig. 3.12 Roughout for a leister prong at Tybrind Vig. It was made from a piece of bent hazel, split through the centre to create two pieces that are mirror images. They would have been bound together at the base and attached to a shaft to create a two-pronged leister. Scale in $\mathrm{cm}$. Drawing by E. Morville, courtesy of Moesgaard Museum Photography Department

willow, pieces of tinder fungus and uncharred remains of sea-beet roots and seeds of manna grass likely used as food. There are also remains of charred food crusts attached to the inner surface of some of the potsherds incorporating evidence of fish bones and plant remains.

These organic remains are remarkable in a number of ways: for the quantity and range of materials and artefacts preserved, which include 


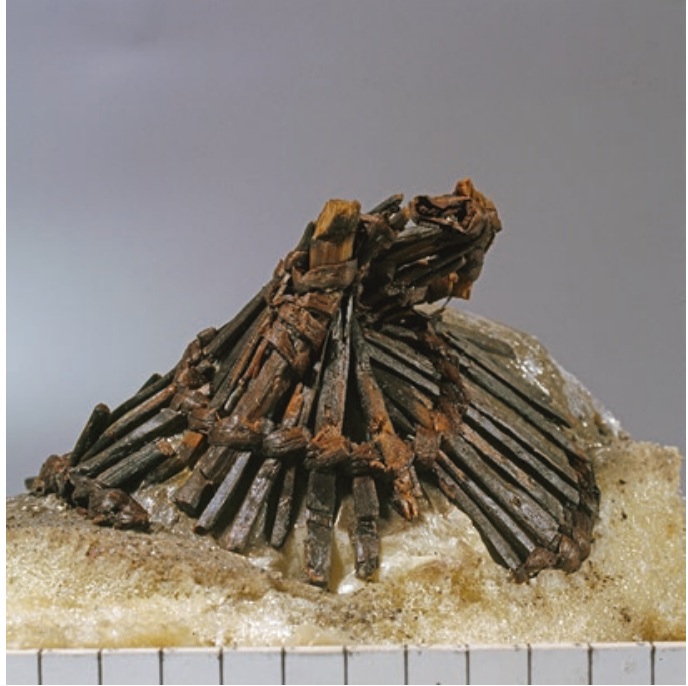

Fig. 3.13 The end of a woven fish trap made from withies of alder and guelder rose. A fist-sized stone was found inside, intended to hold the fish trap down on the seabed. Scale in $\mathrm{cm}$. Courtesy of Moesgaard Museum Photography Department

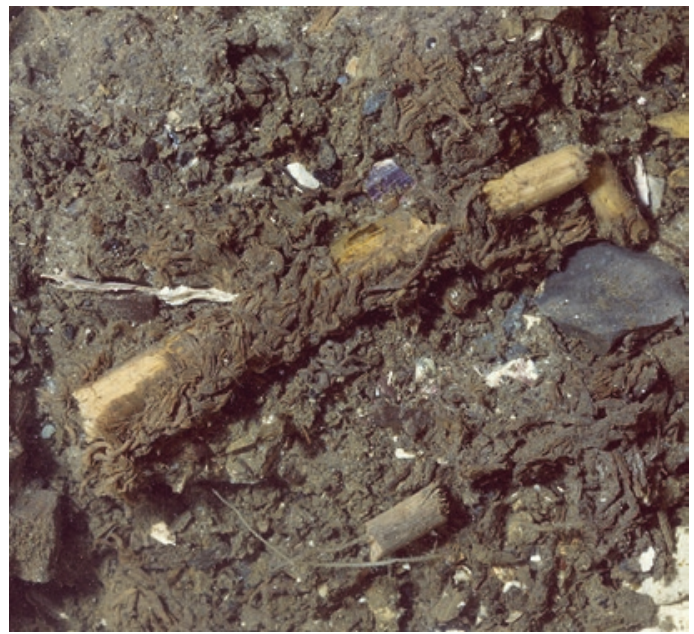

Fig. 3.14 The preservation conditions for plant raw materials at Tybrind Vig were extremely favourable, and many different types of cord, rope and textiles were found. The image shows a stake of hazel wood c. $22 \mathrm{~cm}$ long found in situ in the Tybrind Vig deposit before excavation with a piece of cord tied round it. The cord was made from plant fibres of lime or willow. Photo by Hans Dal, courtesy of Moesgaard Museum Photography Department

examples not previously known about; for details about manufacturing methods and selection of materials, particularly selection of different types

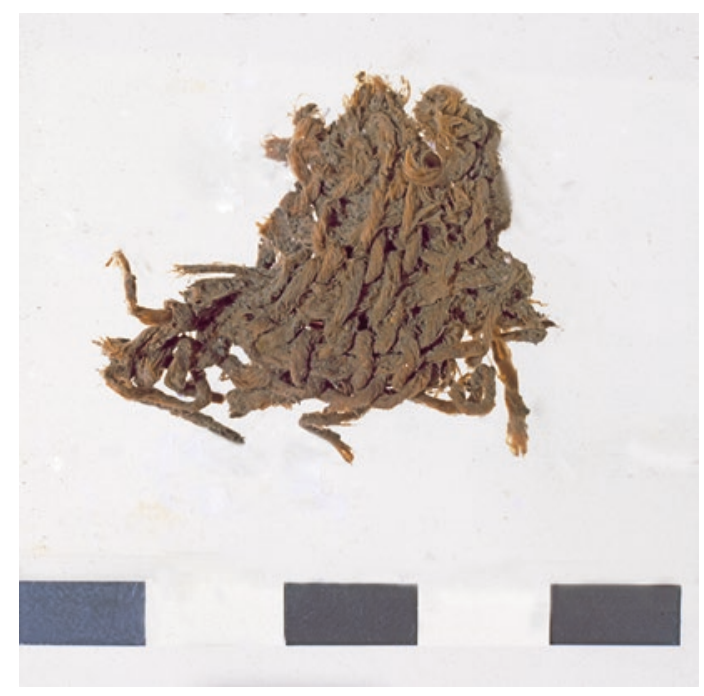

Fig. 3.15 Piece of fabric recovered from Tybrind Vig and woven with 'buttonhole stitching'. The threads were spun from fibres of grass (Gramineae) and willow (Salix sp.) using a $\mathrm{Z}$ (right-hand) twist. Scale in $\mathrm{cm}$. Courtesy of Moesgaard Museum Photography Department

of wood for different purposes; and for additional evidence of the subsistence economy, in particular the great emphasis on fishing, the evidence of equipment used in hunting on land, and the presence of various seeds, roots and other plant foods alongside the more commonly preserved charred remains of hazelnuts and acorns.

Overall, the subsistence economy comprised a combination of marine and terrestrial resources. Fish remains are dominated by cod (Gadus morhua) and flatfish (Pleuronectes, Platichthys), but other species are also present including eels (Anguilla anguilla). Bones of sea mammals indicate hunting especially of grey seal (Halichoerus grypus) and porpoise (Phocoena phocoena), with bones of dolphin (Lagenorhynchus albirostris) and whales (Orcinus orca, Physeter catodon) also present. Gathering of marine molluscs included the ubiquitous oyster (Ostrea edulis). On-land hunting focussed principally on red deer, boar and roe deer and fur-bearing animals, especially pine marten (Martes martes); gathering included a variety of plant foods including roots, berries and nuts. These are represented both by charred remains, notably sea beet (Beta vulgaris spp. maritima), hazelnuts and acorns, and by uncharred 
seeds, notably of manna grass (Glyceria fluitans), raspberry (Rubus idaeus) and strawberry (Fragaria vesca). On the marine side, the combination of food remains and organic artefacts confirms fishing as the major activity and clearly a key determinant of the site location.

\subsubsection{Ronæs Skov, Argus Bank and Møllegabet II}

About $5 \mathrm{~km}$ to the north of Tybrind Vig is the Late Ertebølle site of Ronæs Skov, excavated in eight seasons between 1992 and 2004 using the same excavation and recovery techniques developed at Tybrind Vig. It is a smaller settlement than Tybrind Vig, and was used over a shorter period, between 6.4 and $6 \mathrm{ka}$ during the Late Ertebølle period at a time of slowly rising sea level, but in other respects shows a comparable range of artefacts, preservation conditions and subsistence practices, including fishing, hunting on land and shellgathering. It is the largest of 14 settlements located around the shores of the $3-\mathrm{km}$ long Gamborg Fjord, and like its southerly neighbour was on a south-west facing shoreline opposite a narrow channel, well placed to trap fish or sea mammals entering the fjord.
The dry-land area of the settlement had largely been eroded away, and little was left apart from several stone-lined hearths, three thick vertical wooden poles and a single charred human bone suggesting cremation. One of the hearths contains branches of hazel and hawthorn used as fuel, with a tinder fungus lying alongside (Fig. 3.16), demonstrating both the quality of fragile, organic remains that are preserved in these deposits and the fact that intact features can survive despite the impact of marine erosion (Andersen 2009, p. 46).

The remaining finds, and especially the organic materials, were recovered from a shallow offshore dump area as at Tybrind Vig. Remains of fish weirs in the form of pointed hazel rods, some still in vertical position, and wooden leister prongs, some with impressions left by lashing, indicate the importance of fishing. Wooden bows, spear shafts, axe handles and remains of paddles and canoes, antler axes and a rich ceramic inventory are all present. As at Tybrind Vig, charred food crusts on potsherds give additional insights into the plant materials used in subsistence (Fig. 3.17). Distinctive wooden finds are a single wooden arrow shaft (made from guelder rose, Viburnum opulus) with a transverse microlithic flint held in place by pitch (Fig. 3.18) and some
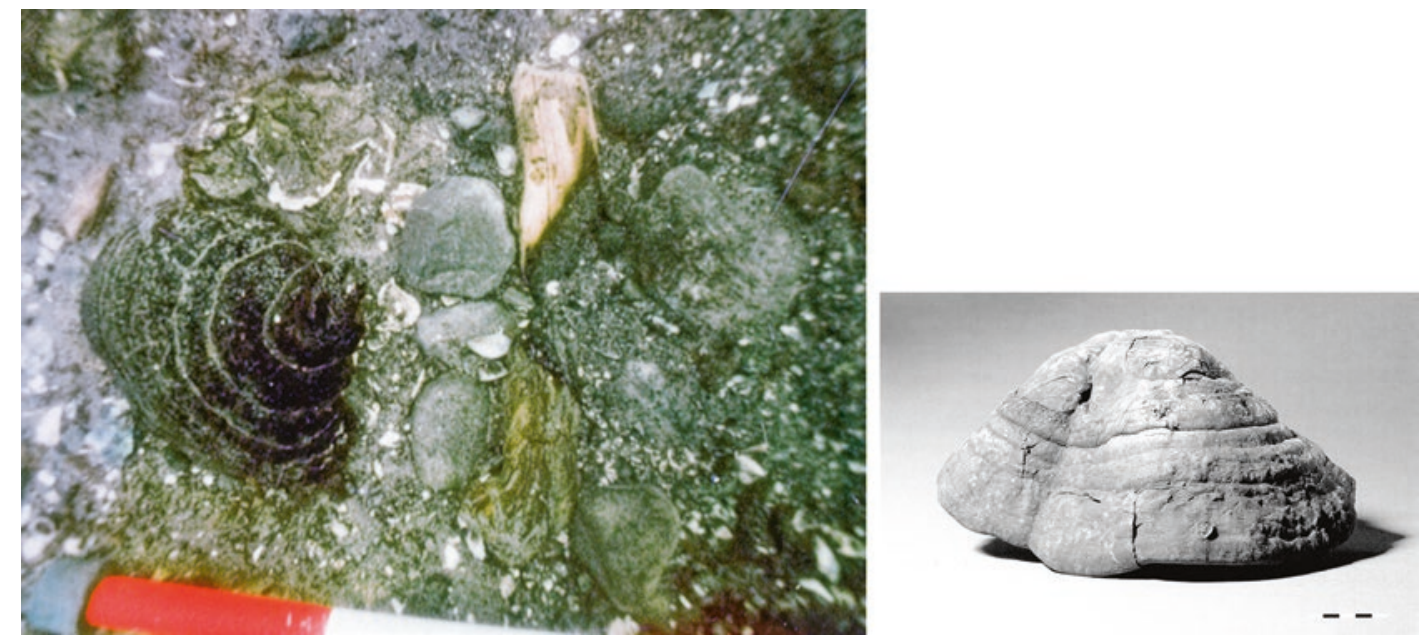

Fig. 3.16 Photo of Ronæs Skov hearth (left) in situ on the seafloor with a ring of soot-blackened stones, two pieces of partially burnt wood, and to the left a tinder fungus, also shown in side view on the right. Tinder fungus is ideal material for lighting fires. Photo on left by Hans Dal. Both photos courtesy of Moesgaard Museum Photography Department 

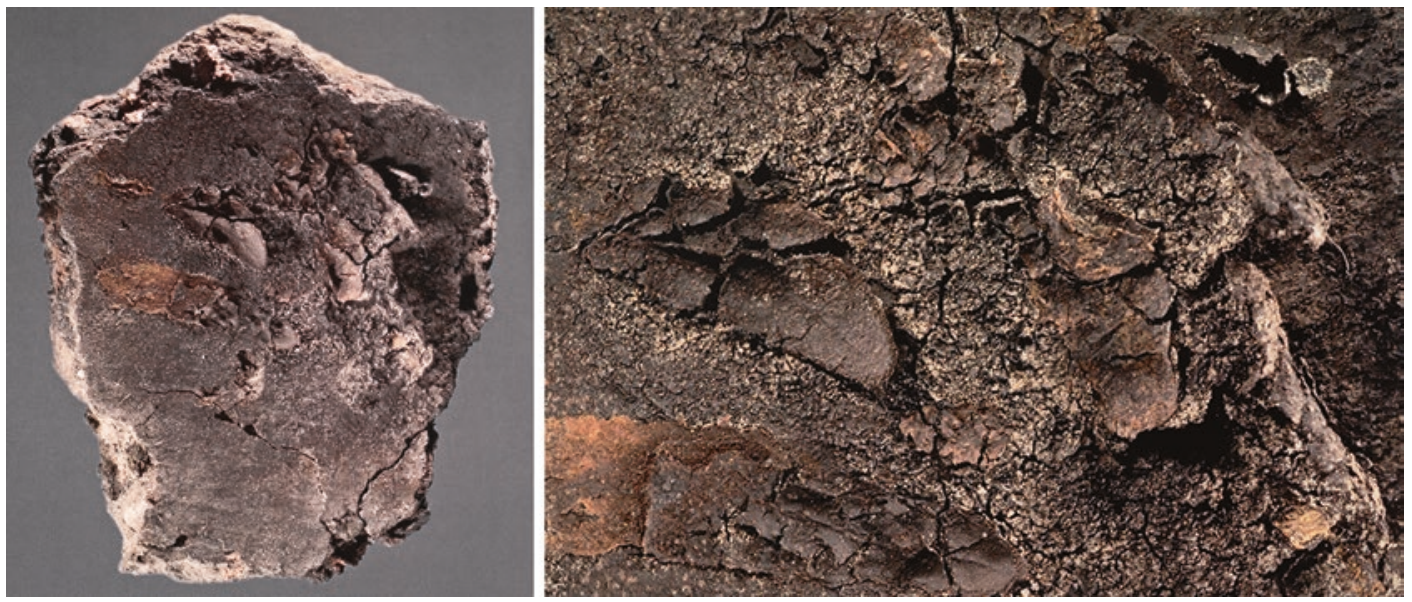

Fig. 3.17 Potsherd from Ronæs Skov with charred food crusts embedded on the inner surface including fragments of mistletoe (Viscum sp.). Left: general view. Right: close up. The sherd is c. $10 \mathrm{~cm}$ long. Photos courtesy of Moesgaard Museum Photography Department

notched sticks interpreted as cross-braces in the construction of fish weirs.

The faunal inventory is comparable to Tybrind Vig, with a slightly greater preponderance of sea mammals (seal, dolphin and whale). This together with the presence of harpoons including refuse from their manufacture and a preponderance of blubber lamps in the ceramic assemblage suggests that the occupants of the site may have taken advantage of the coastal topography not only to trap fish but also to channel sea mammals during their seasonal migrations into the fjord where they could easily be despatched. This interpretation is reinforced by other sites with similar finds on the Jutland shoreline of the Little Belt. Andersen (2009, pp. 213-214, 2013, p. 303) suggests from the dates of these finds an intensification of sea mammal hunting in this region in the Late Ertebølle period, taking advantage of the narrowest and most constricted part of the Little Belt and the 'blind alley' fjords on either side of it. A similar tradition is recorded in historical times in the same region, when up to 36 men in 12 boats engaged in winter hunting of porpoises and dolphins, producing catches of up to 1500 animals (Andersen 2009, p. 214). Even at a conservative estimate, that is enough calories to supply the needs of 500 people for 6 months of the year. The Ertebølle hunt may not have been so intensive and the animal fat was important for heating and lighting as well as for storable food, but these figures nevertheless underline the incalculable importance of sea mammals and the presence of coastal topography that facilitated their capture.

Two other sites to mention here are Argus Bank and Møllegabet II. Both sites are of interest in demonstrating the preservation of intact features on the dry-land surface of the original settlement as well as the presence of offshore dump areas in marine sediments with flint, wood and antler artefacts.

Argus Bank had long been known as a concentration of finds extending over an area of about $50 \times 100 \mathrm{~m}$ at a depth of 4-6 m bpsl as a result of gravel extraction, and a more systematic rescue survey and a small trial excavation were carried out between 1984 and 1986 (Fischer 1987; Fischer et al. 2007a). The majority of the finds (some 3000 artefacts and faunal remains) were recovered during gravel extraction rather than by systematic techniques of archaeological recovery but nevertheless appear to represent a homogeneous assemblage of the Kongemose period. Like many other coastal sites, the Argus site was located on a promontory overlooking a narrow fjord ideal for trapping fish. The main interest of the site is the recovery in the excavated 

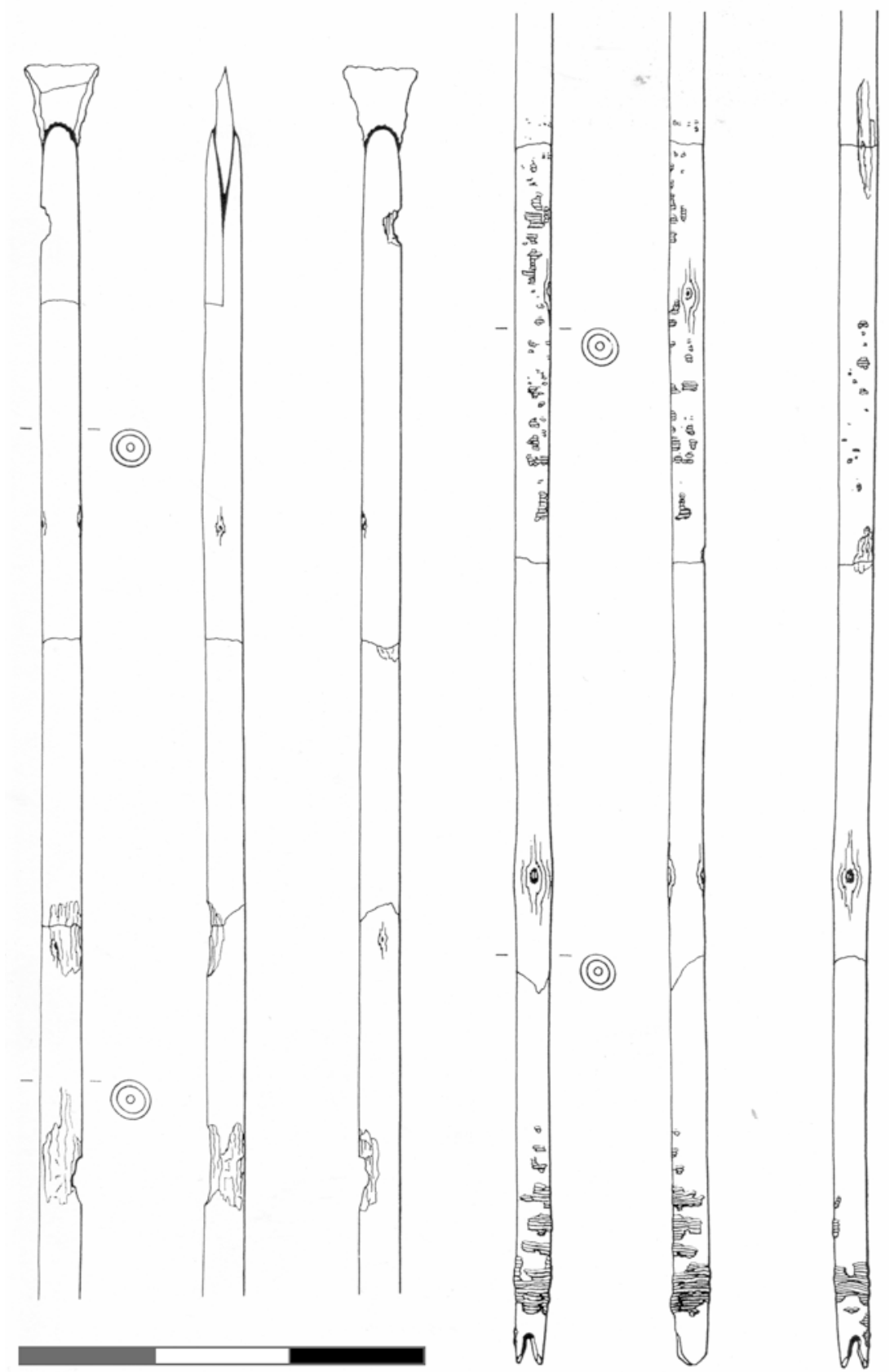

Fig. 3.18 Drawing of a complete arrow shaft from Ronæs Skov, shown in two parts and from three angles. The shaft was found in situ with a transverse arrowhead of flint fixed at the tip with a black pitch-like substance. Traces of a similar material are present at the nock end, presumably for the attachment of feathers. Scale in 10-cm units. Drawing by O. Svendsen, courtesy of Moesgaard Museum Photography Department

area below a sand layer of an intact stone-lined hearth, about $0.5 \mathrm{~m}$ in diameter, with charred branches, ash, burnt flint and charred food remains including hazelnuts, pips of raspberry and blackberry and fish bones, with a date of 5970-5570 cal BC. Redeposited human bones of 
at least four individuals have also been recovered, originating from graves disturbed by erosion or gravel extraction.

Møllegabet II, excavated between 1988 and 1993 (Grøn and Skaarup 2004; Skaarup and Grøn 2004), was discovered by a combination of subbottom acoustic survey and diver inspection at 4.5-5 m bpsl followed up by excavation of a $6 \times 4 \mathrm{~m}$ trench. The site dates to the Early Ertebolle period (c. 5400-4800 cal BC) and is of interest for the discovery of remains of a dugout canoe and parts of a human skeleton nearby, a layer of bark, branches and leaves with concentrations of charcoal, worked flint and fish bones, interpreted as the remains of a dwelling structure and concentrations of mollusc shells that may perhaps represent a shell midden deposit.

\subsection{Underwater Themes: Fish Weirs, Logboats and Shell Mounds}

The results of the excavations summarised above, together with additional findings from more limited or more recent investigations at other sites, have opened up a range of new information about the nature of maritime activities and marine exploitation associated with Mesolithic and Neolithic coastal settlement, in particular the importance of fish weirs and water transport and what the archaeological evidence for these activities indicates about the scale and organisation of coastal settlement. Also of interest is information regarding the differential distribution and preservation of shell middens.

\subsubsection{Fish Weirs}

The wooden stakes and wattles used in the construction of fish weirs are some of the most numerous of the wooden artefacts preserved at these underwater coastal settlements. They are of special interest in demonstrating the considerable investment of communal labour in their construction and maintenance, skills in forest management required to produce the wood for their construction, the importance of fish in the subsistence economy and the volume of food produced by this method of mass capture. They also provide indirect evidence for the presence of permanently inhabited settlements nearby, which would have been necessary to ensure the maintenance of these structures and the regular collection of the trapped fish. The quantities of food obtainable by this method, in their turn, would have provided the supplies necessary to support the resident population at such settlements. Some of the best examples were recovered during rescue excavations at either end of the road and rail link built across the Great Belt, notably at three locations within the narrow 2-km-long Halsskov Fjord: Oleslyst, Halsskov itself and Margrethes Næs (Pedersen and Fischer 1997). ${ }^{4}$

The best preserved is at Oleslyst with two sets of finds dated to the Early and Middle Neolithic period, 3500-2600 cal BC (Pedersen 1997). Here a total of 259 stakes driven into the ground were found to extend in a line for at least $30 \mathrm{~m}$ out from the shore, with a shorter line of stakes forming an acute angle at the seaward end. An almost intact panel was also found lying on its side, some $5.5 \mathrm{~m}$ long and $1.7 \mathrm{~m}$ wide (Fig. 3.19). The panel consisted of 12 upright stakes, $2-4 \mathrm{~cm}$ thick, spaced at $45 \mathrm{~cm}$ intervals. Woven through these uprights were about 50 thinner, flexible hazel withies, forming a tightly woven mesh. The whole structure could originally have been $200 \mathrm{~m}$ long.

${ }^{4}$ The Halsskov Fjord was originally a shallow marine inlet until at least the end of the Middle Neolithic period, but subsequently silted up and was drained in the nineteenth century to create farmland. These sites are not therefore underwater sites in the same sense as those discussed earlier in this chapter. We include them here because the remains were originally deposited on the seabed in shallow water at the shore edge and have remained encased in marine sediments ever since. They are also clearly coastal in nature and are integral to the wider pattern of sites investigated as part of the Great Belt project, which include fully underwater remains. They are a good example of the arbitrary nature of the division between terrestrial and underwater sites and the need sometimes to integrate material on both sides of that the boundary according to the context, as discussed in Bailey et al. (Chapter 1). 


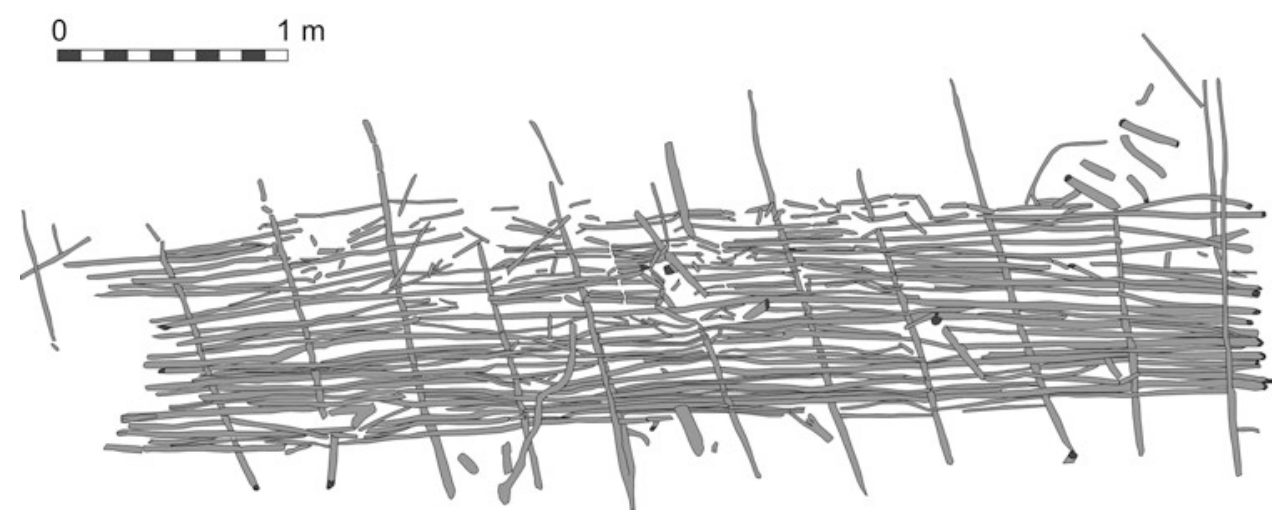

Fig. 3.19 The Oleslyst fishing weir panel, dated to the Early Neolithic. This panel was discovered lying flat on marine sediments and largely intact, except for damage at the left-hand side caused by a machine during excavation. There are 12 uprights consisting of poles of lime or hazel wood 2-4 cm in diameter with pointed bases for driving into the seabed. More flexible hazel withies, $1-3 \mathrm{~cm}$ in diameter, were used as the horizontal members. The longest is $4.5 \mathrm{~m}$ long. These were woven through the uprights to create a tightly meshed panel. Two of the uprights are forked poles, providing additional support for the horizontal withies, and holding the ends of the withies at the right-hand side in a tight grip to facilitate attachment to the neighbouring panel. Isolated wooden stakes representing the uprights of other panels were also found further out from the shore and their distribution shows that these structures were built out for many tens of metres into the sea, with a shorter section constructed at an acute angle at the seaward end to create, in plan, a V-shaped trap, culminating in a pot-shaped fish trap of woven wickerwork. No such trap was found in situ at Oleslyst, but fragments have been found elsewhere (see Fig. 3.13 for an example from Tybrind Vig). After Pedersen (1997, Fig. 6, p. 127), original by L Johansen and L Pedersen, redrawn by G Bailey

Less complete remains of structures interpreted as fish weirs and dating to the Ertebølle period were found at Halsskov, with two examples dated, respectively, at c. 5400 and $4800 \mathrm{cal}$ BC, and at Margrethes Næs, dated at c. $5700 \mathrm{cal}$ $\mathrm{BC}$.

Another well-preserved example is on the island of Neksel $\varnothing$, offshore from the north-west coast of Zealand, with evidence of several different stages of weir construction. The full range of radiocarbon dates suggest a time span from the Late Ertebølle through to the Middle Neolithic with radiocarbon dates of c. 4490-2900 cal BC (Pedersen et al. 2017). However, only two out of 18 radiocarbon dates are Late Ertebølle, and the others cluster in the Early Neolithic and Early Middle Neolithic period, c. 3500-2900 cal BC. Here a line of stakes can be traced out from the shoreline over a distance of $250 \mathrm{~m}$ to a depth of 4-5 m bpsl, and there are indications that it may have extended further out again (Fischer 2007). A 40-m length of wattle panels was found lying in horizontal position, showing a construction of vertical uprights some $5 \mathrm{~cm}$ in diameter with narrower and perfectly straight horizontal hazel withies (Fig 3.20). Estimates for the construction of the $250-\mathrm{m}$ long structure suggest that it would have needed hundreds of vertical poles up to $6 \mathrm{~m}$ long for the main supports and some 6000 straight hazel withies up to $4 \mathrm{~m}$ long for the rest of the structure. This testifies both to the labour-intensive requirements of the construction and to the extent of the coppiced hazel woods that would have to have been maintained to provide the raw materials.

This mesh of hazel woodwork was so tightly constructed as to be almost impenetrable, and Fischer (2007, p. 63) suggests that the design was intended to facilitate the mass capture of European eels, which pass through the Danish Straits in huge numbers during their autumn spawning runs from the Baltic to the Atlantic. Similar traps made from hazel wood were recorded in use in the nineteenth century. The resulting large quantities of eel could have been easily stored for long periods to provide important food reserves for the winter months.

In total, remains of fish weirs are recorded at 17 sites extending through the full chronological span of Mesolithic and Neolithic coastal settle- 


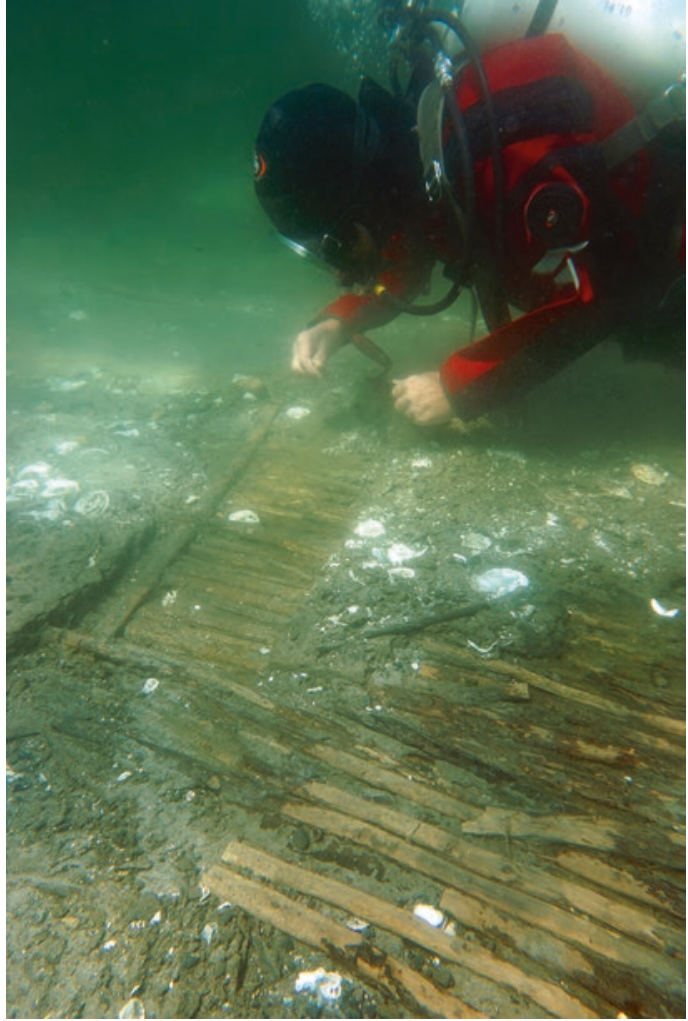

Fig. 3.20 Photo of part of a panel from the Nekselø fish weir, showing closely spaced horizontal hazel withies 2-3 cm thick. Photo by Anne Marie Eriksen, reproduced with permission of The National Museum of Denmark,

ment, from Kalø Vig on the late Maglemoseearly Kongemose boundary at $6450 \mathrm{cal}$ BC through to Ølby Lyng at c. 2900-2350 cal BC. This combination of evidence indicates a 4000-year tradition of construction. However, the Mesolithic examples appear to be simpler and cruder structures made only from hazel wood, whereas the Neolithic fish weirs appear to be larger and stronger with more tightly woven panels and the use of several different types of wood, mainly lime but also including hazel, ash, maple (Acer sp.), elm and oak (Quercus robur). This suggests a development of new and more elaborate construction techniques in the Neolithic period compared to the Ertebølle.

The absence of remains in subsequent millennia may be due to the reduction in accumulation of fine sediments that provide a preserving medium for wooden artefacts, rather than to the abandonment of such fishing practices (Fischer 2007, p. 60).

\subsubsection{Water Transport}

Remains of dugout logboats (canoes) and paddle blades have been recovered from 19 Mesolithic (Ertebølle) sites in Denmark (Andersen 2013, p. 200). Those from Tybrind Vig represent one of the largest assemblages including an almost complete example of a logboat and provide new details about size, construction methods and probable functions (Andersen 2012, 2013).

The complete canoe is $9.5 \mathrm{~m}$ long and c. $0.5 \mathrm{~m}$ wide, with sides that are $2-3 \mathrm{~cm}$ thick (Fig. 3.21). When first discovered it was completely flat, but in its original state the sides would have been $30 \mathrm{~cm}$ high. It was made from a single trunk of a lime tree that must originally have weighed over three tonnes. It was hollowed out by chopping and wedging, reducing the finished weight to about 200-300 kg. The stern was open, presumably with a removable bulkhead, and a hearth next to the stern, indicated by an oval deposit of sand and clay, suggests the possibility of using flares at night to attract fish. There was a smaller hearth indicated by charred material near the front, perhaps indicating use for on-the-spot cooking, and a large $30 \mathrm{~kg}$ stone in the body of the boat which is thought to have acted as ballast or a stabiliser (Fig. 3.21). Experimental work suggests that it would have taken 1-4 weeks of labour for two skilled people to shape such a logboat. The parts of several other canoes show evidence of splitting and the presence of regularly spaced holes around the cracks that indicate the attachment of patches to repair the damage (Fig. 3.22). Similar examples of extensive repair work are well illustrated by the more fragmentary remains of a canoe at the Margrethes Næs site (Myrhøj and Willemoes 1997, p. 160). All of this indicates the investment of time and effort involved in construction and maintenance.

Some 14 paddles or fragments of paddles are present at Tybrind Vig and are made from split timbers of ash to shape the handle and the blade in a single piece. The paddles are about $1 \mathrm{~m}$ long 

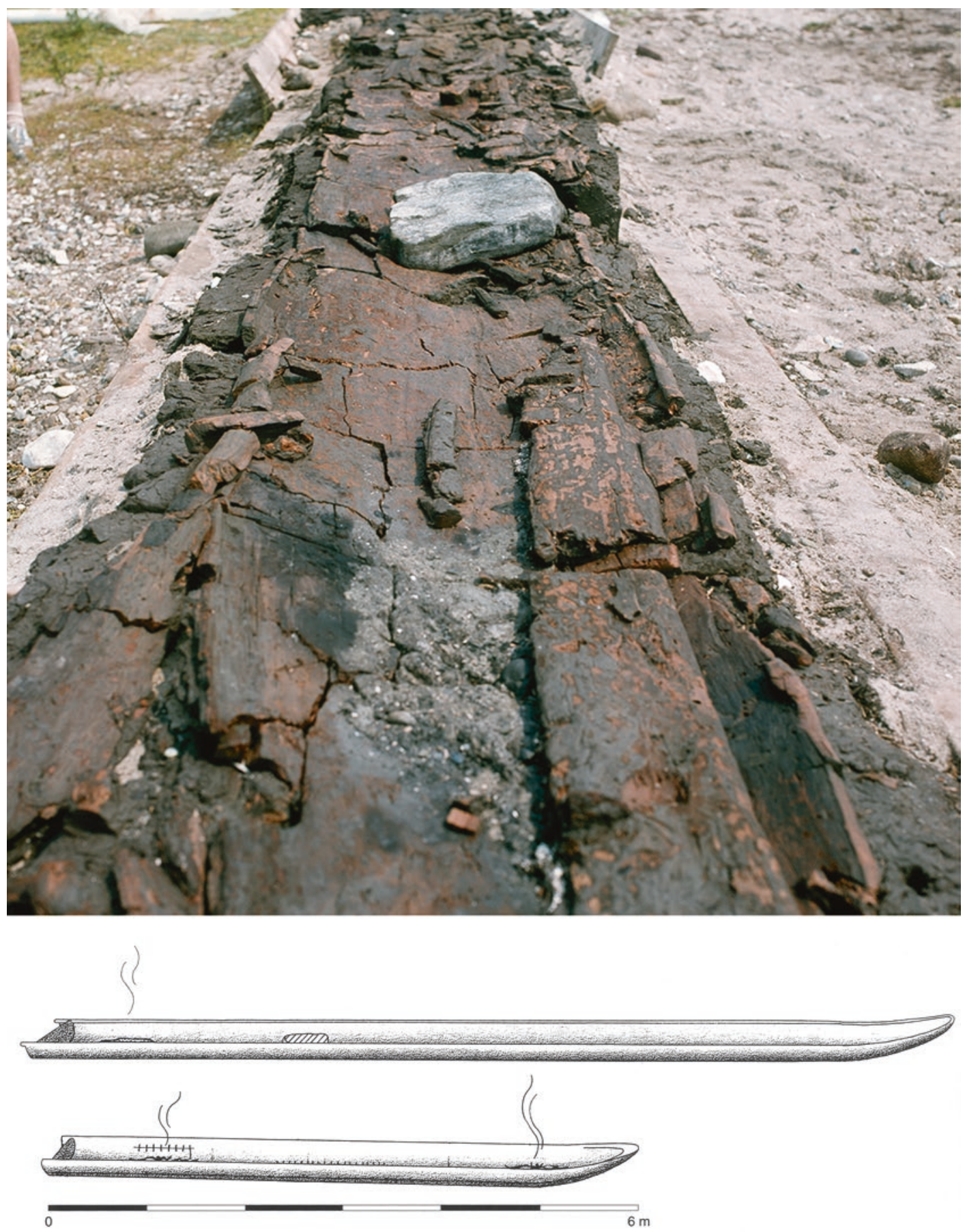

Fig. 3.21 The largest logboat at Tybrind Vig, with a length of $9.5 \mathrm{~m}$. Upper photo: as it looked after removal from its underwater location to dry land. In its original position, it had become flattened, and the sides had collapsed inward. The view is from the stern, with a grey hearth area in the foreground near the stern, and a large ballast stone towards the middle of the boat. Lower image: an artist's reconstruction of the boat shown in the photo and a smaller logboat recovered from the partially submerged site of Lystrup Enge (north of Aarhus), with two hearths. Drawing by O. Svendsen, courtesy of Moesgaard Museum Photography Department 

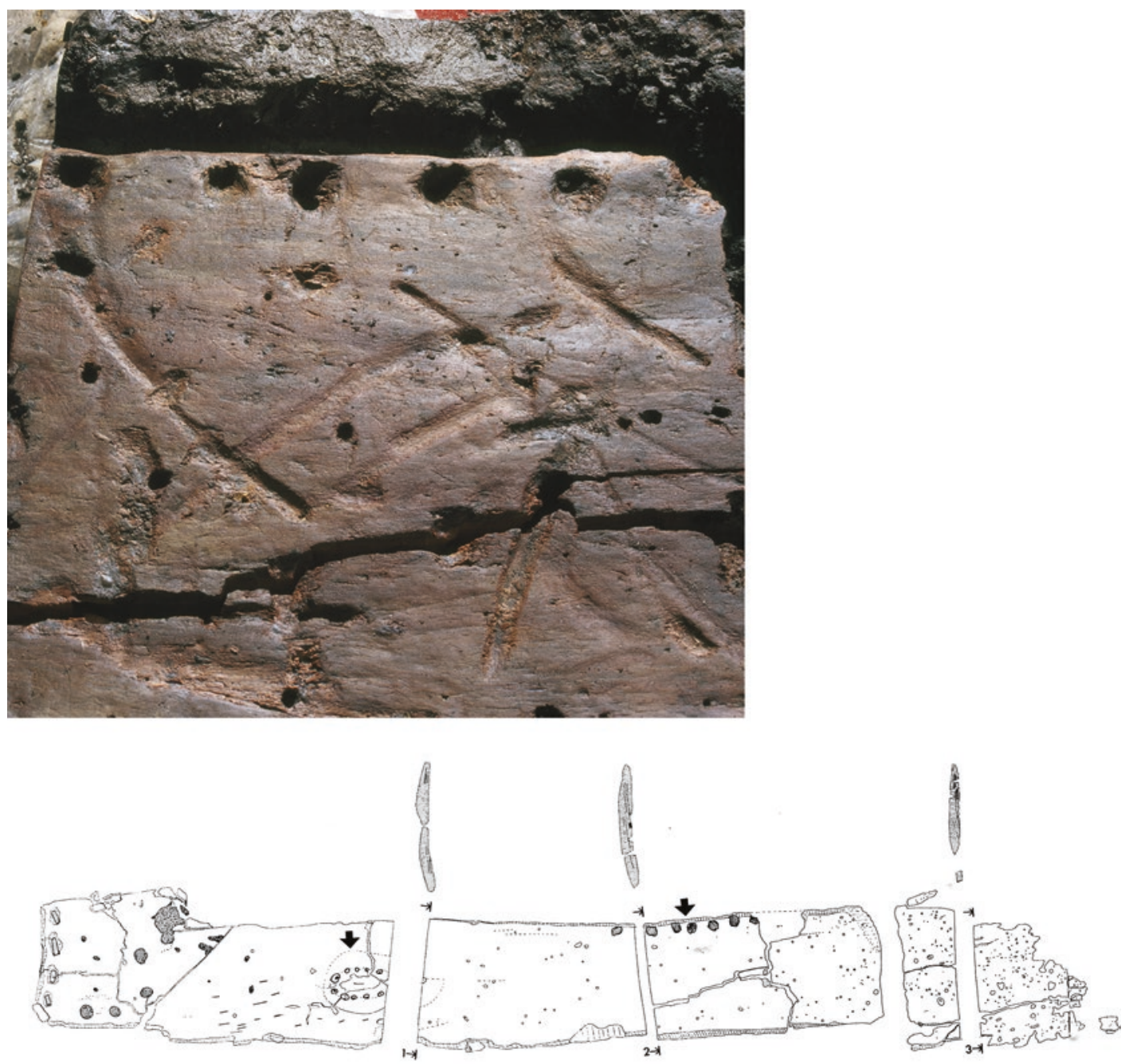

\section{Charred areas (hearth)}

\section{0}

Fig. 3.22 A smaller logboat from Tybrind Vig showing evidence of repair. Lower: the plan of the boat, with the stern on the left and evidence of hearths near the stern. Holes made to assist the repair of cracks are shown by arrows and include the repair of an oval hole originating from a knot in the wood near the stern and a split in the middle section of the boat. Fibres in the holes near the stern suggest that a patch was sewn onto the damaged section. Upper: photo of the holes alongside the split seen on the interior of the boat. Scale in 10-cm units. Plan drawn by J. Dencker and O. Svendsen, plan and photo courtesy of Moesgaard Museum Photography Department

with a stout handle and an oval- or spade-shaped blade not larger than about $20 \times 25 \mathrm{~cm}$ (Fig. 3.23). Some of the paddle blades are richly decorated with carved geometric patterns of lines and dots in different designs, some of which resemble a human face (Fig. 3.24). Some show colouring matter pressed into the inlaid surface. Paddles from other sites show different designs. As visible items, especially when viewed from a distance, these variations in design may have acted as important symbols of ownership and communal identity. The more richly decorated paddles may have served for ceremonial occasions as much as for daily use. 


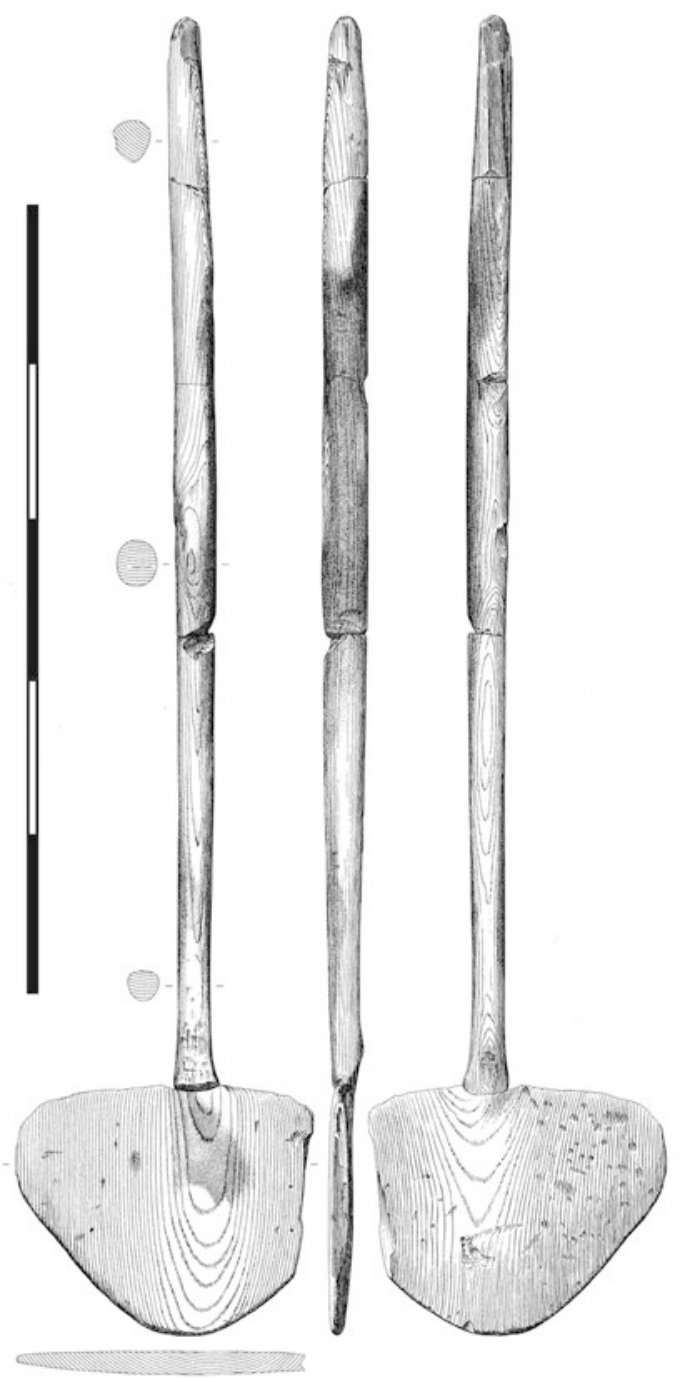

Fig. 3.23 Drawing of a complete paddle recovered from Tybrind Vig. Scale in 10-cm units. Drawn by O. Svendsen. Courtesy of Moesgaard Museum Photography Department

The largest dugout could have carried loads of up to $800 \mathrm{~kg}$, ample to accommodate one or two families of up to eight people and their belongings, or to carry large loads of fish or other resources. They are well suited to short-distance movements in the sheltered waters of the Danish archipelago where they must have played an important role in fishing, sea mammal hunting, the maintenance of fish weirs and the transportation of the catch to the shore, as well as in social communication. They could also be used in more open sea conditions as shown by an experimental crossing of the Øresund in a dugout canoe, which took $5 \mathrm{~h}$ to cover the $15-\mathrm{km}$ distance (Christensen et al. 1979).

The 'boat burial' at Møllegabet II, claimed as evidence of a body in a boat with a bark covering, also suggests the possibility of a ritual use. Whether the Møllegabet example is an authentic boat grave, or the fortuitous co-location on the seabed of human bones and the remains of a boat remains unclear (Skaarup 2004, p. 35; Andersen 2013, pp. 202-203), but better examples are available from the inland bogs of the Neolithic period. Also, stains in the soil around a few graves at Ertebølle coastal sites on dry land have been interpreted as evidence of boats used as containers or coverings for the corpse. The idea of sinking a canoe containing the corpse of an important person covered in a bark shroud remains a plausible if unproven Mesolithic ritual.

\subsubsection{Shell Mounds}

One of the defining characteristics of the Late Mesolithic Ertebølle period is the shell mounds or køkkenmøddinger (kitchen middens)—also known as 'shell middens' or 'shell-matrix sites' (Claassen 1998)—which form such a visually impressive feature of many coastal settlements on the uplifted Littorina shorelines of north-east Denmark (Andersen 2000). These are deposits dominated by shells of marine molluscs discarded as by-products of food consumption, principally oysters (Ostrea edulis) but also including other species such as cockles (Cerastoderma edule) and mussels (Mytilus edulis). The largest middens are several hundred metres long, 30-40 m wide, and $2 \mathrm{~m}$ thick, with a volume of up to $8000 \mathrm{~m}^{3}$. Many are smaller. Mounds of varying size often form clusters around fjords and inlets. In total, there are over 500 Mesolithic shell middens in north-east Denmark, with the majority dating to the Ertebølle period between c. 4900 and $3900 \mathrm{cal} \mathrm{BC}$. The oldest date back to c. 5600-5400 cal BC. Others are known from Neolithic and later periods albeit with cockles or 

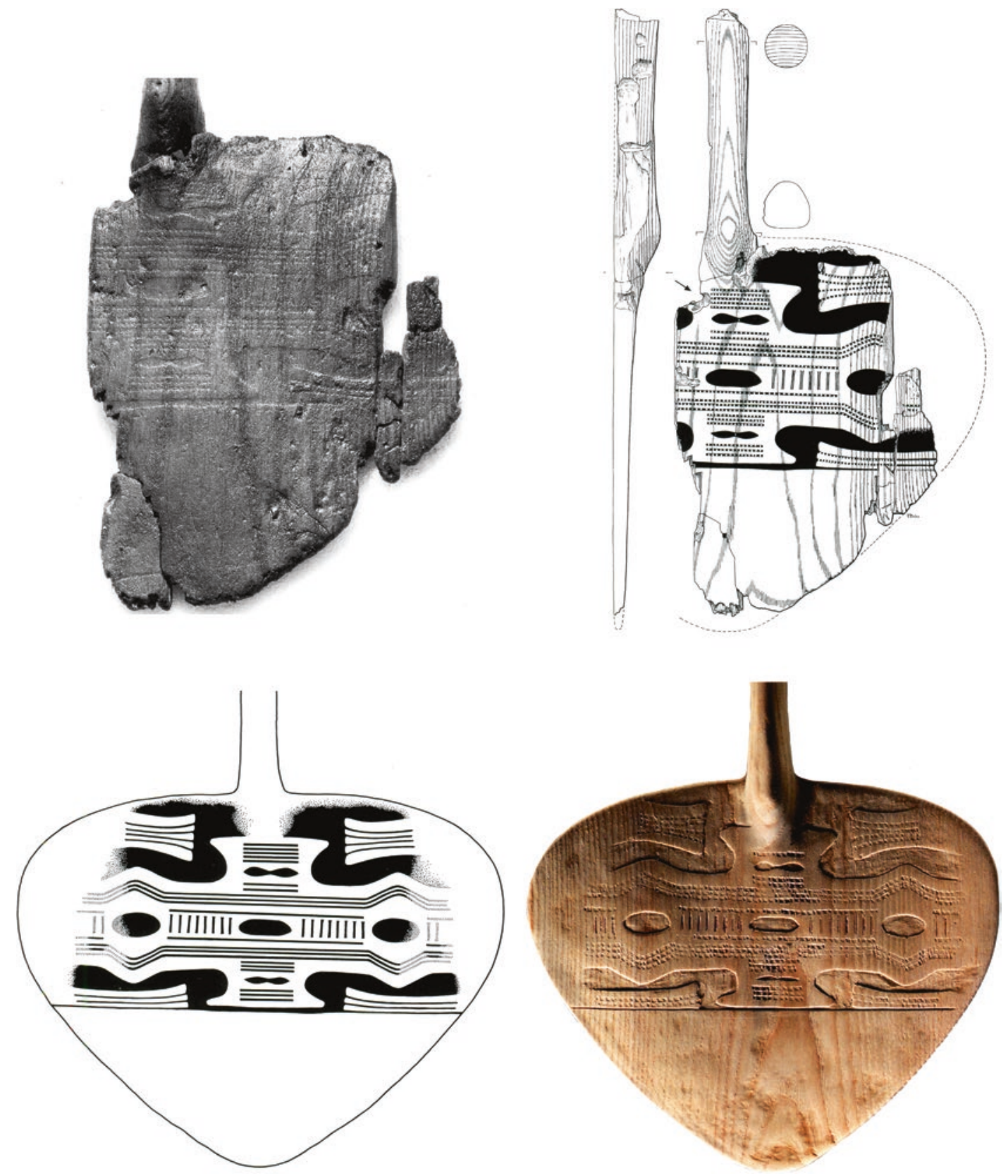

Fig. 3.24 Photograph and drawings of a damaged paddle blade from Tybrind Vig. Top left: the original. Top right: drawing of the decorative patterns. Bottom: a modern reconstruction. Scale in $\mathrm{cm}$. Drawing by F. Bau, courtesy of Moesgaard Museum Photography Department

mussels as the dominant mollusc species rather than oysters (Andersen 2007).

It is now well understood that these Ertebølle shell mounds are coastal settlements with a wide range of artefacts and other food remains includ- ing marine and terrestrial vertebrates and that the oysters contributed a relatively small component of the subsistence economy, though an important one, especially in the late winter and early spring when other food supplies were in short supply 
(Bailey 1978; Milner 2001, 2002). Moreover, contemporaneous coastal settlements lacking shells are just as common in northern Denmark, and in some local fjord regions they are more common than the shell mounds, the presence or absence of shells being determined by the patchy distribution and local availability of the natural shell beds (Andersen 2000, p. 365). Conversely, on the submerged shorelines of southern Denmark, despite the many hundreds of underwater finds that have been recovered, most of them dating to the same time range as the Ertebølle shell mounds of the north, shell middens are almost unknown or subject to uncertainties over their cultural status.

These large, mounded shell deposits are a highly visible marker of coastal settlement and intensive use of marine resources, and similar deposits appear in their hundreds of thousands across the world at about the same time as the Ertebølle sites or slightly earlier in the midHolocene. Comparable deposits are almost unknown from earlier periods, either because earlier populations exploited marine resources less intensively, or because the sites have been drowned and destroyed. Whether similar shell mounds accumulated at earlier periods of low sea level, and, if so, whether they could have survived the erosive power of waves and water currents during inundation by sea-level rise, is thus a question of wide interest. Despite some searches for underwater shell mounds in other parts of the world, and much speculation about whether they could survive the effects of inundation (Bailey 2014; Faught 2014; Nutley 2014), very few have been identified, a notable exception being the recently discovered Econfina site in the Gulf of Mexico (Cook Hale et al. 2018). The Danish underwater evidence therefore provides an important opportunity to investigate this problem.

In fact, edible mollusc shells are present in at least three of the excavated underwater sites discussed above, forming in some cases what looks like a shell midden deposit. However, a major difficulty is determining whether these are genuine in situ shell midden deposits, as opposed to material that has been eroded from the landward side of the shoreline and been redeposited in the dump area where other materials were disposed of, or natural death assemblages of shells-oysters in particular attach themselves to the shells of dead molluscs, resulting in time in quite thick shell banks. There is the additional possibility that shells that have died from natural causes have become mixed with food debris.

At Tybrind Vig, for example, two concentrations of shells are present in and amongst the other remains (see Fig. 3.7; Andersen 2013). The larger deposit covers an area of $5 \times 10 \mathrm{~m}$ and is $50 \mathrm{~cm}$ thick, dominated by oyster shells, along with shells of other edible species. The deposits include some worked flints and animal bones, pieces of worked wood, small twigs, charcoal, bark and hazelnuts, all mixed in with sand and gravel. However, the investigators concluded from the species and age composition of the molluscs, and from the fact that the bivalve shells were often present as paired and closed valves aligned horizontally, that this was a natural shell deposit (Andersen 2013, p. 44). At Ronæs Skov, one of the deposits is a thick layer of oysters and other shells, which Andersen (2009, pp 33-34, p. 210) interprets as an amalgamation of a redeposited shell midden mixed with shells that died naturally. Similar ambiguities apply to the interpretation of the shell deposits described as middens at Møllegabet.

The matter is further complicated by the possibility that oysters may have been less abundant on the now-submerged shorelines of southern Denmark because of progressively reduced salinity and tidal range with increasing distance from the North Sea. Oysters are sensitive to lower salinity, and some indication of this is the evidence for larger and thicker oyster shells in the most northerly shell mounds or at the mouths of fjords, compared to those further south or in inner fjords. However, a wide range of biological indicators demonstrates that the tidal range in the south was greater than today (Petersen 2013) and that the widespread replacement of oysters by cockles as the dominant food species in the upper levels of many Ertebølle shell mounds in the north probably reflects regional or local infilling of bays and estuaries by soft sediments rather than reduction in salinities (Lewis et al. 2016). 
In short, absence of sufficient quantities of available molluscs seems the least likely hypothesis to account for the rarity of underwater shell middens in the south. The causes must lie elsewhere. Regional variation in food preferences is a possibility but we know that at least some molluscs were certainly collected for food in the south, as demonstrated by the evidence of heating on some of the Tybrind Vig shells. Another possibility noted by Fischer (1995, p. 382) is that during a period of rapidly rising sea level, the shoreline would not remain in one place for long enough to allow the stabilisation of shell beds and accumulation of sufficient shells in one place to create a thick deposit. But this cannot apply to the Tybrind Vig site, where the shoreline scarcely moved position during the 1400-year period of occupation. The most likely remaining hypothesis is that shell midden deposits have become degraded and dispersed by marine erosion or are otherwise hidden beneath overlying marine sediments.

Perhaps the best case for a submerged shell midden comes from the recently excavated site of Hjarnø Sund (Fig. 3.25; Skriver et al. 2017; Astrup et al. 2019). Here shell deposits up to $1 \mathrm{~m}$ thick have been discovered beneath gyttja and eroding out at the surface of the seabed (Fig. 3.26). The accumulation of oyster shells looks like a typical midden deposit as known from terrestrial examples on the uplifted shorelines of north-east Denmark rather than a natural shell bank, and the deposits contain worked flints, abundant fish bones, mammal bones and concentrations of charcoal indicating a settlement area with a hearth. Investigations are ongoing at this site and it should be possible to develop suitably sensitive techniques for discriminating between cultural and natural shell deposits found in underwater settings.

\subsection{Conclusion}

The number of underwater finds of Mesolithic age from Danish waters is by any standards extraordinary. Where detailed work has been undertaken, it is clear that almost the whole shoreline represents a palimpsest of archaeological sites and materials of different ages, different types and in varying
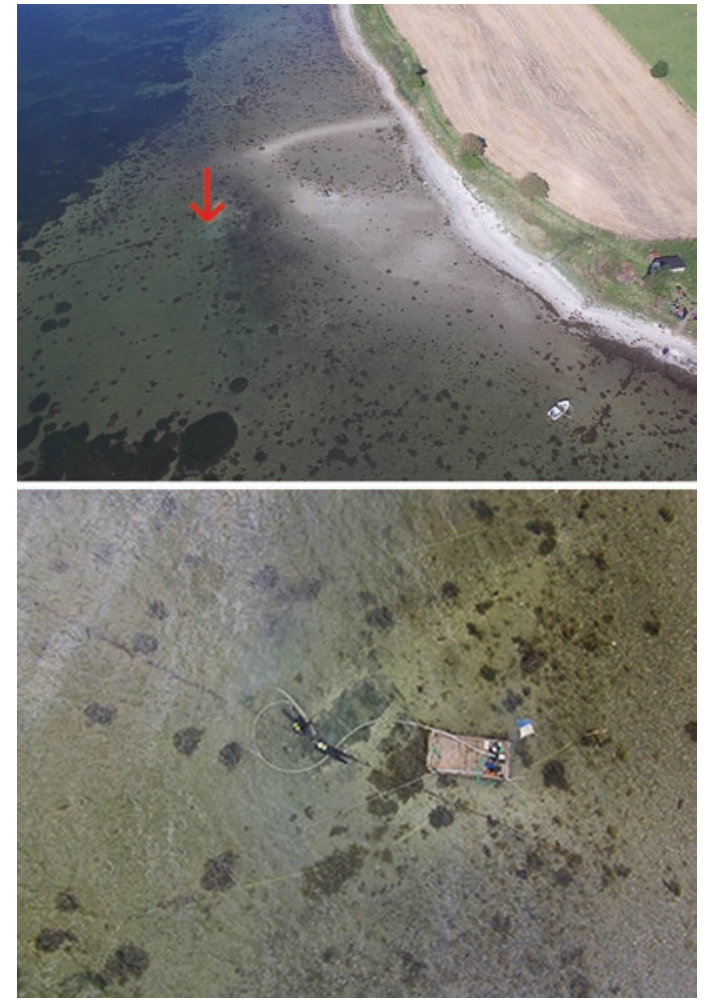

Fig. 3.25 Aerial view of the Hjarn $\varnothing$ underwater site. Upper: general view with the location of the site marked by a red arrow. Lower: close up of site during excavation, showing pontoon with equipment and two divers excavating under water. Photos courtesy of Peter Moe Astrup and Jonathan Benjamin

states of preservation distributed over many kilometres. Notable examples of underwater site density are the Gamborg Fjord (14 sites within a 2-km radius) and the Tybrind Vig cove (seven sites within a $1-\mathrm{km}$ radius). If we include the Halsskov Fjord referred to earlier, the site density is nine within a $1 \mathrm{~km}$ radius. This compares with 33 sites within a $5-\mathrm{km}$ radius on the uplifted shoreline around the somewhat larger Bjørnsholm Fjord in northern Jutland (Andersen 2000, p. 365). Some of the underwater finds are single artefacts, dropped or lost during daily subsistence activities, others are permanent settlements with a wide range of resources and year-round settlement associated with fish weirs, others again are smaller sites used for particular purposes such as flintknapping or mooring of dugout canoes, and some are collections of redeposited material disturbed 


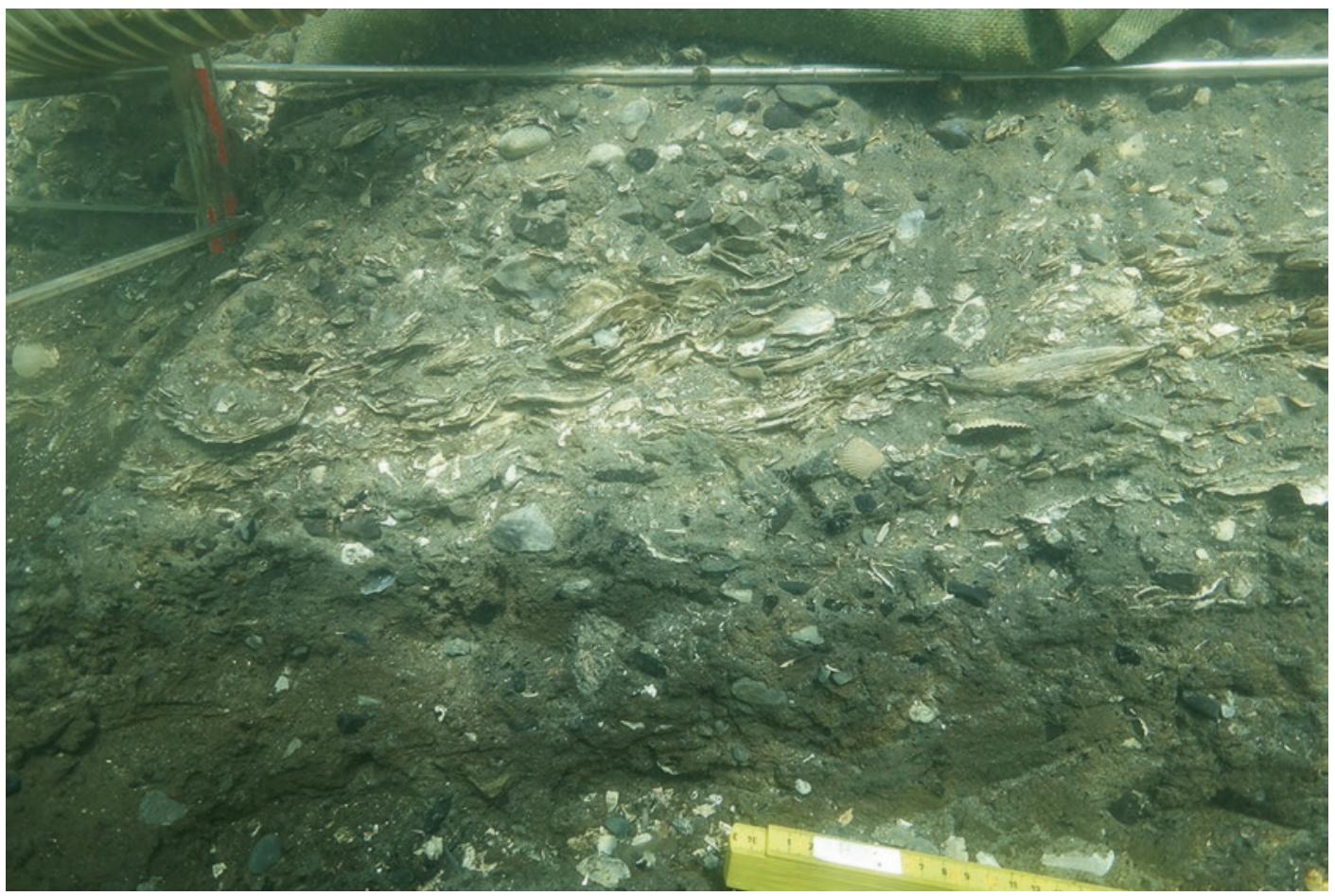

Fig 3.26 Section through an underwater shell midden deposit at Hjarnø. Photo by Peter Moe Astrup

by marine erosion. Similar conditions are found in fjords and inlets around many coastlines of the Danish archipelago. It is little surprise that the number of underwater prehistoric sites is estimated to be many thousands, and that no comprehensive or accurate inventory has yet been completed. Moreover, recently undertaken work driven by research questions rather than rescue operations underlines the fact that much of what is already known about or recorded represents only what is most obviously visible and most easily reached from the shoreline and in shallow water, or most visibly at risk from destruction, and that much more may remain hidden beneath marine sediments (Uldum et al. 2017).

\subsubsection{Preservation Conditions Revisited}

This brings us back to the question raised at the beginning of this chapter about the factors that have contributed to this extraordinary richness of underwater material, how it has altered archaeological interpretation and whether similar conditions and concentrations of finds might be found on coastlines in other areas of Europe or beyond. In addition to the general factors noted in the introduction, two other features stand out from the detailed examination of individual sites presented above. The first is the dense concentration of population and settlement along the shoreline, a fact that reflects the very high biological productivity of an archipelago environment with straits and fjords, mixing of currents and high levels of marine fertility, sheltered conditions for sea travel and shallow channels and bays with narrow entrances highly favourable to the trapping of migratory fish and sea mammals. In fact, the Danish Straits as a whole represent a largescale funnel or trap between the Kattegat to the north-west and the Baltic to the south-east, providing unusual conditions of ecological diversity and productivity of marine resources and ease of access to them, especially to the whales, fish and eels that would have migrated in large numbers 
between the Baltic and the North Sea in search of seasonal feeding and breeding grounds. Similar conditions are present on other coastlines in Europe and elsewhere or may have existed at earlier periods when sea level was lower than present, though perhaps nowhere with quite the same configuration and concentration of opportunities for human exploitation. There is, therefore, every reason to expect comparable evidence in other areas with similar topographic and ecological conditions, subject only to the vagaries of postdepositional destruction and visibility.

A second factor is the shallow offshore topography and patterns of sedimentation associated with Danish sites and patterns of refuse disposal or in situ activity that resulted in the primary deposition of large quantities of material in shallow water. Excavation sections typically show an upward fining of sediments from coarser sand and gravel to fine clay or gyttja, reflecting a slight but slowing rise in sea level. Gyttja provides an ideal sediment for ensuring the rapid burial of discarded materials and their encasement in anaerobic conditions, which are maintained indefinitely as long as the material remains submerged and permanently waterlogged.

These soft sediments and anaerobic conditions have preserved large numbers of wooden artefacts. These include fish weirs and other equipment used in fishing, a factor previously underestimated, large dugout canoes with a considerable load-bearing capacity of high importance in facilitating subsistence activities at the coast and social interaction and communication in an otherwise heavily forested landscape, and new aspects of art.

However, preservation is far from perfect. Even material rapidly buried in gyttja remains vulnerable to piddocks, molluscs that bore holes into submerged wood and stone, and wooden materials can be compressed and damaged by the pressure of overlying sediments. Also, large areas of these underwater settlements have been damaged by marine erosion during the process of inundation particularly the dry-land areas on the landward side of the shoreline, with dispersal, redeposition and destruction of material. This emphasises the point that, even in the relatively gentle marine con- ditions of these Danish shorelines, sea-level rise is fundamentally a destructive process. Yet, not everything is destroyed. The hearths at Ronæs Skov and Argus Bank have been noted above, and there are similar examples from other sites, such as Halsskovholmen and Horsekær in the Great Belt (Pedersen et al. 1997). It is likely that some of the small items and more fragile remains found in gyttja deposits such as pieces of nutshell or charcoal and traces of hearths represent in situ activities originally carried out on the gyttja surface at low tide, which were then rapidly covered by sediment (Andersen 2013, p. 69). Traces of a possible dwelling structure have also been identified, which may represent a short-lived structure located on the foreshore. Graves on the original land surface with their human skeletons sometimes survive intact, perhaps because they were already partly protected by burial in the subsoil. The chances of survival on these land surfaces must depend on how rapidly material was covered by protective marine sediments, but the conditions that favour the preservation and discovery of these localised pockets of survival admit of no easy generalisations. The taphonomic processes of archaeological site formation and deformation in underwater settings are nothing if not complex.

An additional insight into preservation conditions is provided by the effect of eel grass (Zostera marina), which can form an extensive cover of vegetation on the seabed in shallow water and consolidate the underlying sediments. Over recent decades, the eel grass has been affected by disease and begun to disappear, making the underlying sediment more vulnerable to erosion and in the process exposing much of the underlying archaeology and bringing it to archaeological attention (Fischer 2004; Andersen 2013, p. 7). As this has consequences beyond archaeology, these changes are subject to intense research with reference to future management of the archaeological resource as well (Höffle et al. 2011). This process highlights the double-edged effect of sediment cover, which can both protect the original land surface but also hide it from view, and the equally doubleedged effect of sediment removal, which can reveal the presence of submerged archaeology but also accelerate its destruction. 
Overall, the preservation and investigation of the submerged Danish coastal landscape is exceptional in terms of the concentration and geographical extent of the archaeological material present, but there is no reason to suppose that similar conditions cannot be found elsewhere or on more deeply submerged shorelines, though they may be more isolated and patchier in their distribution.

\subsubsection{Future Challenges}

One of the positive outcomes of underwater research in Denmark over the past four decades is the demonstration that underwater archaeological deposits can be excavated with the same thoroughness and accuracy as archaeological sites on dry land, with techniques suitably adapted to working with divers under water (Dal 2013). Even so, despite the many records of underwater sites in Denmark, very few have been subjected to test pitting let alone to full-scale excavation as at Tybrind Vig. Moreover, work has mainly concentrated on shallow-water sites and therefore by definition those in the most recent (Late Ertebølle) period of the Mesolithic sequence. This risks creating an impression of increased population growth and intensification of maritime activities through time that may be quite false.

Meanwhile, national funding of necessity is focussed on development-led rescue work associated with offshore constructions or sites obviously at risk of erosion, but without the resources to sustain post-excavation analysis and publication to the same standards as research-led investigations, except in rare cases such as the Great Belt project (Pedersen et al. 1997), further compounding the sampling bias and the backlog of incompletely recorded material (see Uldum et al. 2017, pp. 69-70).

Traces of fish weirs, offshore refuse areas and wooden materials have been identified from some of the earliest sites that have been investigated, back to c. $6500 \mathrm{cal} \mathrm{BC}$. Moreover, it is clear from stable isotope reconstructions of human diet from inland skeletons and other indicators that marine foods were on the menu from at least as early as the Maglemose period (Fischer et al. 2007b). The presumption must be that people began to colonise the coastlines of the Danish archipelago as soon as the region was inundated by sea-level rise, perhaps as early as c. $7500 \mathrm{cal} \mathrm{BC}(9500 \mathrm{cal}$ $\mathrm{BP})$, and that shorelines with their access to marine resources favoured major concentrations of population and settlement as in later periods. But that is a proposition that can only be tested by systematic excavation of more deeply submerged sites, and this is an obvious target for future research.

Similar comments apply to the very extensive submerged landscape offshore of Denmark's Atlantic coastline. This region has been rather overshadowed by the focus on the Danish Straits, but we know from occasional finds dredged up by chance including the Maglemose artefact from the Danish sector of the Dogger Bank noted above (see Fig. 3.4), that this was an important prehistoric landscape. And it is here that evidence for use of coastlines in significantly earlier periods-Late Palaeolithic or earlier-will have to be sought.

Another realisable target is the development of a digital database of existing records. These represent a rich source of material for analysis and for planning of future research. The SPLASHCOS Viewer represents a first step in that direction, but the records are still incomplete and organised in the form of a spreadsheet rather than a searchable database. Further development will require resources and skilled personnel and most likely research-led funding.

These targets have been on the agenda for many years (e.g. Fischer 2007) but with little significant progress. The costs and logistical complexities of underwater work, especially in deeper water, should not be overlooked. But a new generation of acoustic technologies and trained archaeological divers are now available to tackle such challenges. Multibeam bathymetry, subbottom profiling and side-scan sonar are routine techniques applied in offshore and deep-water surveys and could be deployed to apply predictive models like the fishing-site model — and others-in more deeply submerged terrain. International collaboration is now firmly on the 
agenda and European or international funding increasingly available to facilitate research-led investigations, with some recent examples in Denmark (Uldum et al. 2017; Benjamin et al. 2018; Astrup et al. 2019). The existing underwater work in Denmark provides an excellent platform for reaching out to these more challenging objectives. Institutional infrastructure with the potential to combine scientific and archaeological facilities is available in Copenhagen and Aarhus through their respective universities and associated museums (Roskilde and Moesgaard). This in its turn offers the potential to create a world centre of expertise and training. The increasing threat of destruction to underwater material by natural processes and commercial activities adds urgency to the development of a new era of Danish-led research into submerged landscape archaeology.

\subsection{Management of the Underwater Cultural Heritage}

Since the establishment of the interdisciplinary 'kitchen midden committee' in 1848, the development of Danish prehistoric archaeology has integrated issues of climate change and coastal protection for which coastal shell-mounds form such a distinctive marker (Sørensen 1898; Brinch Petersen 2015, p. 209). In early legal protection, no clear distinction was made between finds or sites on land and under water. It was only in 1969 that underwater prehistoric remains were explicitly brought under protective legislation, and 1984 saw the extension of protective regulations to the seabed up to the 24-mile limit (Kristiansen 1985; Lund 1987). In doing so, Denmark effectively established an unprecedented cultural heritage protection zone in accordance with the Contiguous Zone regulations of the UN Law of the Sea Convention (Lund 1987; Dromgoole, Chapter 25, this volume). In accordance with these responsibilities, the central government agency for nature and cultural heritage conservation created a special unit for the inventory, registration and inspection of underwater finds
(Thomsen 1987). This work constituted the basis for a central database, which integrated information collected through the intricate network of regional and local museums (Smed 1987). The contributions of sports divers, the general public and amateur archaeologists to this work have traditionally been substantial (Fischer and Sørensen 1983; Skaarup 1983; Dal 2013).

At present, the Agency for Culture and Palaces under the Ministry of Culture remains the central authority responsible for government decisions relating to specific underwater sites or to underwater cultural heritage in general. It is also the central clearing house for the administration of relevant data and management of the central database. The acquisition of data, other than through agreement with other offices, is largely decentralized to museums that are recognized by the State under the 'Museum Law'. In total, Denmark has 97 such museums, of which 5 have been assigned a seabed area for which they are archaeologically responsible. The Viking Ship Museum in Roskilde is responsible for the waters around Zealand and Bornholm; Langelands Museum is responsible for the archipelagic waters around Fyn, whereas Moesgaard Museum and the two museum organizations that manage the coastal museums in northern Jutland and on the west-coast share responsibility for the North Sea, the Skagerrak and the Kattegat.

The National Museum, with a remit to advise on conservation matters, houses a small unit addressing issues related to degradation and in situ preservation of underwater sites, as well as conservation and restoration of waterlogged finds (Gregory 2017; Strætkværn et al. 2013). Activities by this unit in the field are always undertaken in close cooperation with the responsible museum. The same holds true for research undertaken by universities. Of these, Copenhagen University is relevant through its prehistoric-archaeological, geological and seismological research, while Aarhus University cooperates closely with Moesgaard Museum for research in their area of responsibility. The Maritime Archaeology Programme at the University of Southern Denmark (MAP-SDU) focuses specifically on the training of archaeological staff for 
development-led archaeology at sea and maintains close ties with the other institutions mentioned (Maarleveld 2009). It is likely that Aarhus University will take over this role when MAPSDU will be closed in the near future.

As in many other countries, the professionalisation of archaeological interventions that are development-led and paid for by the developer has led to a lesser involvement of sports divers, amateur archaeologists and others lacking the necessary professional qualifications for offshore work and a reduced impetus for research-led investigations. Moreover, not all research archaeologists have embraced development-led practice as a practicable strategy for their research, and not all mitigation contracts stipulate adequate research strategies. Although the consequences of this shift are hard to gauge, it can nevertheless be mentioned that new finds not related to developmentled surveys continue to be reported, although not necessarily through the five earmarked museums (Lauridsen 2013). Furthermore, it remains a challenge that the distribution of responsibilities makes for very small units, including one or two maritime archaeologists only, and hence gives little leeway for proactive deployment offshore. A further issue with decentralisation - not unique to Denmark - is that regional or local government generally has little interest in what happens far out at sea, whether inside or outside the cultural heritage protection zone (Maarleveld 2007). Moreover, Denmark has not ratified the 2001 UNESCO Convention. Strict registration and a focus on preservation limit the possibilities for proactive research, even in the context of development-led interventions. Nevertheless, research that leads to better understanding of the past has been and still is the pre-eminent reason for the protection and management of the non-renewable scientific resource, especially in or on the seabed, where other possibilities to enjoy heritage are limited (Lund 1995, p. 416).

Acknowledgements We are grateful to Peter Moe Astrup and Harry Robson for a critical reading of the text, to Peter Moe Astrup and David Gregory for assistance with images and to Anders Fischer for assisting with the compilation of site data for the SPLASHCOS Viewer.

\section{References}

Andersen SH (1980) Tybrind Vig. Foreløbig meddelelse om en unders $\varnothing$ isk stenalderboplads ved Lillebælt. Antikvariske Studier 4:7-22

Andersen SH (1985) Tybrind Vig. A preliminary report on a submerged Ertebølle settlement on the west coast of Fyn. J Dan Archaeol 4:52-69

Andersen SH (2000) Køkkenmøddinger (Shell middens) in Denmark: a survey. Proc Prehist Soc 66:361-384

Andersen SH (2005) En glittestok fra Dogger Banke i Nordsøen. Kuml:9-15

Andersen SH (2007) Shell middens ("Kokkenmфddinger") in Danish prehistory as a reflection of the marine environment. In: Milner N, Craig OE, Bailey GN (eds) Shell middens in Atlantic Europe. Oxbow, Oxford, pp 31-53

Andersen SH (2009) Ronæs Skov. Marinarkæologiske undersøgelser af en kystboplads fra Ertebølletid, Jysk Arkæologisk Selskabs Skrifter 64. Jysk Arkæologisk Selskab, Højbjerg

Andersen SH (2012) Ertebølle canoes and paddles from the submerged habitation site of Tybrind Vig, Denmark. In: Benjamin J, Bonsall C, Pickard C, Fischer A (eds) Submerged prehistory. Oxbow, Oxford, pp 1-20

Andersen SH (2013) Tybrind Vig. submerged mesolithic settlements in Denmark, Jutland Archaeological Society Publications Vol. 77. Jutland Archaeological Society, Højbjerg

Astrup PM (2018) Sea-level change in Mesolithic southern Scandinavia: Long- and short-term effects on society and the environment, Jutland Archaeological Society Publications Vol. 106. Jutland Archaeological Society, Højbjerg

Astrup PM, Skriver C, Benjamin J, Ward I, Stankewicz F, Ross P, McCarthy J, Baggaley P, Ulm S, Bailey G (2019) Underwater shell middens: excavation and remote sensing of a submerged Mesolithic site at Hjarn $\varnothing$, Denmark. J I Coast Archaeol 1-20. https:// doi.org/10.1080/15564894.2019.1584135

Bailey GN (1978) Shell middens as indicators of postglacial economies: a territorial perspective. In: Mellars PA (ed) The early postglacial settlement of northern Europe. Duckworth, London, pp 37-63

Bailey GN (2014) New developments in submerged prehistoric archaeology: an overview. In: Evans AM, Flatman JC, Flemming NC (eds) Prehistoric archaeology on the continental shelf. A global review. Springer, New York, pp 291-300

Benjamin J, O'Leary M, Ward I, Hacker J, Ulm S, Veth P, Holst M, McDonald J, Ross PJ, Bailey GN (2018) Underwater archaeology and submerged landscapes in Western Australia. Antiquity Project Gallery. Available at https://doi.org/10.15184/aqy.2018.103

Björck S (1995) Late Weichselian to early Holocene developments of the Baltic Sea - with implications for coastal settlements in the southern Baltic region. In: Fischer A (ed) Man and sea in the Mesolithic: coastal settlement above and below present sea 
level. Proceedings of the International symposium, Kalundborg, Denmark 1993. Oxbow Monograph 53. Oxbow, Oxford, pp 23-34

Brinch Petersen E (2015) Between the 1820s and 1900: Discovering the Køkkenmøddings and the Older Stone Age (Mesolithic) of Denmark. In: Bicho N, Detry C, Price TD, Cunha E (eds) Muge 150th: the 150th anniversary of the discovery of Mesolithic shellmiddens - Volume 2. Cambridge Scholars, Cambridge, pp 207-218

Christensen C (1995) The Littorina transgressions in Denmark. In: Fischer A (ed) Man and sea in the Mesolithic: coastal settlement above and below present sea level. Proceedings of the International symposium, Kalundborg, Denmark 1993. Oxbow Monograph 53. Oxbow, Oxford, pp 15-22

Christensen K (1997) Oak trunks from the Halsskov Fjord. In: Pedersen L, Fischer A, Aaby B (eds) The Danish Storebælt since the Ice Age: Man, sea and forest. A/S Storebæltsforbindelsen, Copenhagen, pp 37-44

Christensen K (2013) Dendrochronological analysis of oak trunks from Tybrind Vig. In: Andersen SH, Tybrind Vig. Submerged Mesolithic settlements in Denmark. Jutland Archaeological Society Publications Vol 77. Jutland Archaeological Society, Højbjerg, pp 365-376

Christensen C, Nielsen AB (2008) Dating Littorina sea shore levels in Denmark on the basis of data from a Mesolithic coastal settlement on Skagens Odde, northern Jutland. Polish Geological Institute Special Papers 23:27-38

Christensen C, Grønnow B, Hansen CV, Jøhnsson JH, Malmros C, Petersen PV (1979) Stammebåden. Et eksperiment med udhugning og sejlads. Nationalmuseets Arbedjsmark 1979:89-94

Claassen C (1998) Shells. Cambridge University Press, Cambridge

Cohen KM, Westley K, Erkens G, Hijma MP, Weerts HJT (2017) The North Sea. In: Flemming NC, Harff J, Moura D, Burgess A, Bailey GN (eds) Submerged landscapes of the European continental shelf: quaternary paleoenvironments. Wiley, Chichester, pp 147-186

Cook Hale JW, Hale NL, Garrison EG (2018) What is past is prologue: excavations at the Econfina Channel site, Apalachee Bay, Florida, USA. Southeast Archaeol. https://doi.org/10.1080/0734578X.2018.1428787

Dal H (2013) The marine-archaeological investigations 1978-1987. Organisation, equipment and excavation techniques. In: Andersen SH, Tybrind Vig. Submerged Mesolithic settlements in Denmark. Jutland Archaeological Society Publications Vol 77. Jutland Archaeological Society, Højbjerg, pp 505-527

Degerbøl M (1943) Om dyrelivet: Aamosen i Stenalderen. In Matthiassen $\mathrm{T}$ et al (eds) Stenalderbopladsen $\mathrm{i}$ Aamosen. Nordiske Fortidsminder III Bind, 3 Hefte. Kongelige Nordiske Oldskriftselskab, pp 165-206
Dencker J, Jensen SO (2000) Nye stenalderfund fra havets dyb. Fløjstrup Skov, Århus Bay. Marinarkæologisk Nyhedsbrev fra Roskilde 13:18-19

Faught MK (2014) Remote sensing, target identification and testing for submerged prehistoric sites in Florida: process and protocol in underwater CRM projects. In: Evans AM, Flatman JC, Flemming NC (eds) Prehistoric archaeology on the continental shelf. A global review. Springer, New York, pp 37-52

Fischer A (1987) Stenalderbopladsen på Argusgrunden En 7000-årig bebyggelse på bunden af Smålandsfarvandet. In: Kristiansen K, Fischer A (eds) Fortidsminder og Kulturhistorie, Antikvariske Studier 8. Skov- og Naturstyrelsen, København, pp 11-58

Fischer A (1993) Stone Age settlements in the Småland Bight: a theory tested by diving (In Danish and English). Miljøministeriet, Skov- og Naturstyrelsen, København

Fischer A (1995) An entrance to the Mesolithic world below the ocean. Status of ten years' work on the Danish sea floor. In: Fischer A (ed) Man and sea in the Mesolithic: coastal settlement above and below present sea level. Proceedings of the International symposium, Kalundborg, Denmark 1993. Oxbow Monograph 53. Oxbow, Oxford, pp 371-384

Fischer A (1997) Drowned forests from the Stone Age. In: Pedersen L, Fischer A, Aaby B (eds) The Danish Storebælt since the Ice Age: Man, sea and forest. A/S Storebæltsforbindelsen, Copenhagen, pp 29-36

Fischer A (2004) Submerged Stone Age - Danish examples and North Sea potential. In: Flemming NC (ed) Submarine prehistoric archaeology of the North Sea. Research priorities and collaboration with industry, CBA Research Report 141. Council for British Archaeology, York, pp 23-36

Fischer A (2007) Coastal fishing in Stone Age Denmark evidence from below and above the present sea level and from human bones. In: Milner N, Craig OE, Bailey GN (eds) Shell middens in Atlantic Europe. Oxbow, Oxford, pp 54-69

Fischer A, Malm T (1997) The settlement in the submerged forest in Musholm Bay. In: Pedersen L, Fischer A, Aaby B (eds) The Danish Storebælt since the Ice Age: Man, sea and forest. A/S Storebæltsforbindelsen, Copenhagen, pp 78-86

Fischer A, Sørensen SA (1983) Stenalder på danske havbund. Antikvariske Studier 6:104-126

Fischer A, Vang Petersen P (2018) Denmark - a sea of archaeological plenty. In: Fischer A, Pedersen L (eds) Oceans of archaeology. Jutland Archaeological Society. Aarhus University Press, Aarhus

Fischer A, Richards M, Olsen J, Robinson DE, Bennike P, Kubiak-Martens L, Heinemeier J (2007a) The composition of Mesolithic food. Evidence from the submerged settlement on the Argus bank, Denmark. Acta Archaeol 78(2):163-178

Fischer A, Olsen J, Richards M, Heinemeier J, Sveinbjörnsdóttir AE, Bennike P (2007b) Coast- 
inland mobility and diet in the Danish Mesolithic and Neolithic: evidence from stable isotope values of humans and dogs. J Archaeol Sci 34:2125-2150

Gehrels WR, Szkornika K, Bartholdy JR, Kirby R, Bradley SL, Marshall WA, Heinemeiere J, Pedersen JBT (2006) Late Holocene sea-level changes and isostasy in western Denmark. Quat Res 66(2):288-302. https://doi.org/10.1016/j.yqres.2006.05.004

Gregory D (2017) Out of sight but not out of mind: research into the in-situ preservation of marine archaeological sites. SDU, Esbjerg

Grøn O, Skaarup J (1993) Møllegabet II. A submerged Mesolithic site and a "boat burial" from Ærø. J Dan Archaeol 10:38-50

Höffle H, Thomsen MS, Holmer M (2011) High mortality of Zostera marina under high temperature regimes but minor effects of the invasive macroalgae Gracilaria vermiculophylla. Estuar Coastal Shelf Sci 92(1):35-46

Holm J (1991) Settlements of the Hamburgian and Federmesser cultures at Slotseng, South Jutland. J Dan Archaeol 10:7-19 Odense

Houmark-Nielsen M, Kjær HK (2003) Southwest Scandinavia, 40-15 kyr BP: palaeogeography and environmental change. J Quat Sci 18(8):769-786

Jensen JJ, Bennike O, Witkoski A, Lemke W, Kuijpers A (1997) The Baltic Ice Lake in the southwestern Baltic: sequence-, chrono- and biostratigraphy. Boreas 26(3):217-236

Kristiansen K (1985) Fortidsmindebevaring i Danmark. Status og fremtidsperspektiver. Antikvariske Studier 7:142-164

Larsson L (2017) Submerged settlements in the Öresund, western Scania, southernmost Sweden. In: Bailey GN, Harff J, Sakellariou D (eds) Under the sea: archaeology and palaeolandscapes of the continental shelf. Springer, Cham, pp 165-175

Lauridsen JG (2013) Bearbejdet oldtidsrav fra kysten omkring Blåvandshuk. Arkæologi i Slesvig. Archäologie in Schleswig 14:9-17

Lewis JP, Ryves DB, Rasmussen P, Olsen J, Knudsen $\mathrm{K}-\mathrm{L}$, Andersen SH, Weckström K, Clarke AL, Andrén E, Juggins S (2016) The shellfish enigma across the Mesolithic-Neolithic transition in southern Scandinavia. Quat Sci Rev 151:315-320

Lund C (1987) Beskyttelse af historiske skibsvrag og fortidsminder på den danske havbund. Antikvariske Studier 8:135-150

Lund C (1995) Legislation, protection and management of underwater cultural heritage - the Danish model. In: Fischer A (ed) Man and sea in the Mesolithic: coastal settlement above and below present sea level. Proceedings of the International symposium, Kalundborg, Denmark 1993. Oxbow Monograph 53. Oxbow, Oxford, pp 415-418

Maarleveld TJ (2007) Maritime management matters. In: Satchell J, Palma P (eds) Managing the marine cultural heritage: Defining, accessing and managing the resource, CBA Research Report 153. Council for British Archaeology, York, pp 49-58
Maarleveld ThJ (2009) Maritime archaeology - status and identity? In Müller U, Kleingärtner S, Huber F (eds) Zwischen Nord- und Ostsee 1997-2007 Zehn Jahre Arbeitsgruppe für maritime und limnische Archäologie (AMLA) in Schleswig-Holstein. Rudolf Habelt, Bonn pp 51-62

Malm T (1995) Excavating submerged Stone Age sites in Denmark - the Tybrind Vig example. In: Fischer A (ed) Man and sea in the Mesolithic: coastal settlement above and below present sea level. Proceedings of the International symposium, Kalundborg, Denmark 1993. Oxbow Monograph 53. Oxbow, Oxford, pp 385-396

Momber G, Peeters H (2017) Postglacial human dispersal and submerged landscapes in North-West Europe. In: Bailey G, Harff J, Sakellariou D (eds) Under the sea: archaeology and palaeolandscapes of the continental shelf. Springer, Cham, pp 321-334

Mathiasen DR (1997) The changing landscapes of the Storebælt, from the retreat of the ice to the sea flood. In: Pedersen L, Fischer A, Aaby B (eds) The Danish Storebælt since the Ice Age: Man, sea and forest. A/S Storebæltsforbindelsen, Copenhagen, pp 22-28

Milner N (2001) At the cutting edge: using thin sectioning to determine season of death of the European Oyster, Ostrea edulis. J Archaeol Sci 28:861-873

Milner N (2002) Incremental growth of the European oyster Ostrea edulis: seasonality information from Danish kitchenmiddens, Oxford: British Archaeological Reports International Series 1057. Archaeopress, Oxford

Myrhoj M, Willemoes A (1997) Wreckage from the Early Stone Age. In: Pedersen L, Fischer A, Aaby B (eds) The Danish Storebælt since the Ice Age: Man, sea and forest. A/S Storebæltsforbindelsen, Copenhagen, pp 157-166

Nokkentved C, Anderson RT, Folke H, Linton MIA, Anderson SV (2018) Denmark. https://www.britannica.com/place/denmark. Updated 27 February 2018

Nutley D (2014) Inundated site studies in Australia. In: Evans AM, Flatman JC, Flemming NC (eds) Prehistoric archaeology on the continental shelf. A global review. Springer, New York, pp 255-273

Påsse T, Andersson L (2005) Shore-level displacement in Fennoscandia calculated from empirical data. GFF 127(4):253-268

Pedersen L (1997) They put fences in the sea. In: Pedersen L, Fischer A, Aaby B (eds) The Danish Storebælt since the Ice Age: Man, sea and forest. A/S Storebæltsforbindelsen, Copenhagen, pp 124-143

Pedersen L, Fischer A (1997) Stone Age fishers at Halsskov Fjord. In: Pedersen L, Fischer A, Aaby B (eds) The Danish Storebælt since the Ice Age: Man, sea and forest. A/S Storebæltsforbindelsen, Copenhagen, pp 108-205

Pedersen L, Fischer A, Aaby B (eds) (1997) The Danish Storebælt since the Ice Age: Man, sea and forest. A/S Storebæltsforbindelsen, Copenhagen 
Pedersen L, Fischer A, Gregory DJ (2017) Fletværket ved Nekselø - skovdrift og storstilet fiskeri i bondestenalderen. Nationalmuseets Arbejdsmark 2017:134-145

Petersen KS (2013) The geological conditions in and around Tybrind Vig at the time of the Ertebølle settlement, as revealed by the marine molluscan fauna. In: Andersen SH, Tybrind Vig. Submerged Mesolithic settlements in Denmark. Jutland Archaeological Society Publications Vol. 77. Jutland Archaeological Society, Højbjerg, pp 355-361

Petersen KJ, Rasmussen KL (1995) Late Weichselian and Holocene changes in the marine environment - with examples from north West Denmark. In: Fischer A (ed) Man and sea in the Mesolithic: coastal settlement above and below present sea level. Proceedings of the international symposium, Kalundborg, Denmark 1993, Oxbow monograph, vol 53. Oxbow, Oxford, pp 35-38

Rosentau A, Bennike O, Uscinowicz S, MiotkSzpiganowcz G (2017) The Baltic Sea Basin. In: Flemming NC, Harff J, Moura D, Burgess A, Bailey GN (eds) Submerged landscapes of the European continental shelf: quaternary paleoenvironments. Wiley, Chichester, pp 103-133

Sistermans P, Nieuwenhuis O (2018) Erosion Case Study: Western Coast of Jutland. Published online at: http://copranet.projects.eucc-d.de/files/00011__ EUROSION_West_coast_of_Jutland.pdf. Accessed 2018

Skaarup J (1983) Submarine stenalderbopladser i Det sydfynske øhav. Antikvariske Studier 6:137-161 København

Skaarup J (2001) Stenalderbopladser på havbunden - status og fremtid. Det Arkæologiske Nævn, Roskilde

Skaarup J (2004) Introduction and background. In: Skaarup J, Grøn O (eds) Møllegabet II. A submerged Mesolithic settlement in southern Denmark, BAR International Series 1328. Archaeopress, Oxford, pp 1-3

Skaarup J, Grøn O (2004) Møllegabet II. A submerged Mesolithic settlement in southern Denmark, BAR International Series 1328. Archaeopress, Oxford

Skriver C, Borup P, Astrup PM (2017) Hjarnø Sund: an eroding Mesolithic site and the tale of two paddles. In:
Bailey GN, Harff J, Sakellariou D (eds) Under the Sea: archaeology and palaeolandscapes of the continental shelf. Springer, Cham, pp 131-143

Smed P (1987) Undersøiske fortidsminder - registreing af fund fra den danske havbund. Antikvariske Studier 8:161-187

Sørensen W (1898) Hvem er opdageren af steenalders affaldsdynger ("Kjøkkenmødingerne")? En historisk redegjørelse. Thaning \& Appel, Kjøbenhavn

Sørensen SA (2017) The Kongemose Culture. Nordiske Fortidsminder, Serie B, Bind 27. The University Press of Southern Denmark, Odense

Strætkværn K, Gøtche M, Pentz P, Hjelm Petersen A, Solow M, Nørlem Sørensen J (2013) Undervejs med verdens længste vikingeskib. Nationalmuseets Arbejdsmark 2013:24-37

Thomsen B (1987) Registrering af fortidsminder og historiske vrag på havbunden - en foreløbig status. Antikvariske Studier 8:151-160

Uldum O, Benjamin J, McCarthy J, Feulner F, Lübke H (2017) The Late Mesolithic site of Falden, Denmark: results from underwater archaeological fieldwork and a strategy for capacity-building based on the SPLASHCOS mission. In: Bailey GN, Harff J, Sakellariou D (eds) Under the Sea: archaeology and palaeolandscapes of the continental shelf. Springer, Cham, pp 65-84

Uścinowicz S (2003) Relative sea level changes, glacioisostatic rebound and shoreline displacement in the southern Baltic, Polish Geological Institute Special Papers 10. Polish Geological Institute, Warsaw

Uścinowicz S (2014) The Baltic Sea continental shelf. In: Chiocci FL, Chivas AR (eds) Continental shelves of the world. Geological Society, Memoirs 411, pp 111-144

Vang Petersen P, Johansen L (1991) Sølbjerg I an Ahrensburgian site on a reindeer migration route through eastern Denmark. J Dan Archaeol 10(1):20-37. Odense. https://doi.org/10.1080/01084 64X.1991.10590051

Westley K (2017) The northern shelf. In: Flemming NC, Harff J, Moura D, Burgess A, Bailey GN (eds) Submerged landscapes of the European continental shelf: quaternary paleoenvironments. Wiley, Chichester, pp 135-145

Open Access This chapter is licensed under the terms of the Creative Commons Attribution 4.0 International License (http://creativecommons.org/licenses/by/4.0/), which permits use, sharing, adaptation, distribution and reproduction in any medium or format, as long as you give appropriate credit to the original author(s) and the source, provide a link to the Creative Commons licence and indicate if changes were made.

The images or other third party material in this chapter are included in the chapter's Creative Commons licence, unless indicated otherwise in a credit line to the material. If material is not included in the chapter's Creative Commons licence and your intended use is not permitted by statutory regulation or exceeds the permitted use, you will need to obtain permission directly from the copyright holder.

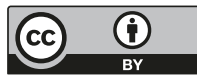

